\title{
Structural properties of adsorbent phyllosilicates rule the entrapping ability of intercalated iron-phenanthroline complex towards thiols
}

\author{
Elena Castellini, Daniele Malferrari *, Fabrizio Bernini, Adele Mucci, Marco Borsari, Maria Franca Brigatti \\ Department of Chemical and Geological Sciences, University of Modena and Reggio Emilia, Via Campi 103, I-41125 Modena, Italy
}

\section{A R T I C L E I N F O}

\section{Keywords:}

clays

Sepiolite

Iron

Phenanthroline

Hybrid materials

Gas trapping

Sulfur

\begin{abstract}
A B S T R A C T
The interaction of volatile organic sulfur derivatives, such as 1-heptanethiol $\left(\mathrm{C}_{7} \mathrm{H}_{16} \mathrm{~S}\right)$, with clay minerals treated with a $\mu$-oxo $\mathrm{Fe}^{3+}$-phenanthroline 1:1 complex results strongly affected by crystal chemical properties of pristine mineral phases. In particular, two sepiolite clays with different structural features demonstrated significantly different ability to immobilize the $\mathrm{Fe}^{3+}$-phenanthroline complex at two $\mathrm{pH}$ values $(\mathrm{pH}=5.4$ and $\mathrm{pH}=2.3$ ). The most effective binding was obtained with sepiolite with higher structural disorder at $\mathrm{pH}$ 5.4. Accordingly, the resulting hybrid material showed also the greatest efficiency in removal of thiol in gas phase. A direct correlation can be established between the adsorption of the $\mathrm{Fe}^{3+}$-phenanthroline complex and the gas binding process at room temperature. In fact, 1-heptanethiol entrapping occurs via redox reactions between $\mathrm{Fe}^{3+}$ and a first thiol molecule to give the reduced $\mathrm{Fe}^{2+}$-phenanthroline complex and disulfide, followed by the binding of further thiols to the reduced metal centre. The extremely high amount of thiol immobilized by the hybrid material also suggests the co-presence of a catalytic mechanism that guarantees the reoxidation of $\mathrm{Fe}^{+2}$ to $\mathrm{Fe}^{+3}$ and the restoration of redox reactions with thiol. Investigation and conclusions were supported by the several experimental techniques: elemental analysis, X-ray powder diffraction analyses, UV-Vis measurements, FT-IR and NMR spectroscopies, thermogravimetric analyses.
\end{abstract}

\section{INTRODUCTION}

Volatile organic sulfur derivatives, such as 1-heptanethiol $\left(\mathrm{C}_{7} \mathrm{H}_{16} \mathrm{~S}\right)$, are smelly pollutants commonly observed in natural environments and as a result of human activities. The immobilization of sulfur-bearing gas phases is thus a key target in environmental remediation.

Sepiolite, with ideal half-cell composition $\mathrm{Mg}_{8} \mathrm{Si}_{12} \mathrm{O}_{30}(\mathrm{OH})_{4} \cdot 4\left(\mathrm{OH}_{2}\right) \cdot \mathrm{nH}_{2} \mathrm{O}$, is a fibrous octahedral Mg-rich layer silicate typically occurring as fine-grained, poorly crystalline aggregate $[1,2]$. The widely accepted structure model, in the orthorhombic space group Pnan, was firstly proposed in 1956 by Brauner and Preisinger [3]. Sepiolite structure (unit cell parameters $\left.a \times b \times c=13.405 \times 27.016 \times 5.275 \AA^{3}, \quad \alpha=\beta=\gamma=90^{\circ}\right) \quad$ consists of an alternation of blocks and cavities that grow up along the fibres direction ( $c$-axis). Each block consists of two tetrahedral sheets (T) sandwiching an octahedral sheet (M). The $\mathrm{T}$ sheet is continuous, thanks to a periodic inversion in the orientation of the apical oxygen atoms, which point alternatively up and down, bonding either to the upper or to the lower discontinuous $\mathrm{M}$ sheet. Each block is connected to its neighbour through an inverted $\mathrm{Si}-\mathrm{O}-\mathrm{Si}$ bond. Tunnels measure approximately $3.7 \times 10.6 \AA^{2}$ in cross section and account in large part for the high specific surface area and excellent sorption properties related to several active sites, i.e., i) $\mathrm{OH}$-anions coordinated to $\mathrm{Mg}$ octahedral sites; ii) structural $\mathrm{H}_{2} \mathrm{O}$ which completes the $\mathrm{Mg}$ octahedral site coordination at the edge of the tunnels; iii) four zeolitic $\mathrm{H}_{2} \mathrm{O}$ positions inside sepiolite tunnels [4,5] (Fig. 1). Furthermore, the periodic inver-

Abbreviations: SP1, Sepiolite SP-1 (Valdemoro, Spain); EB, Sepiolite EB (Elbuur, Central Somalia); Fe ${ }^{3+} \mathrm{phen}\left[\left(\mathrm{OH}_{2}\right)_{3}(\mathrm{Phen}) \mathrm{FeOFe}(\mathrm{Phen})(\mathrm{OH})_{3}\right]^{+4}$; HPT, 1-heptanethiol;

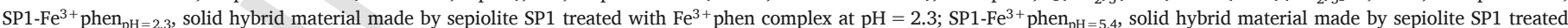

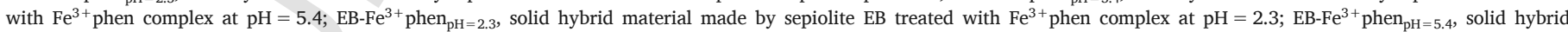

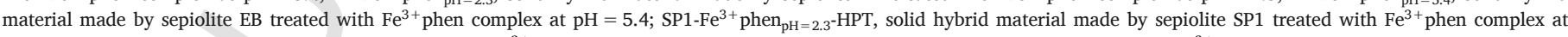

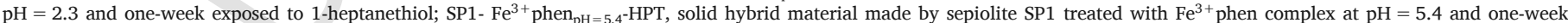

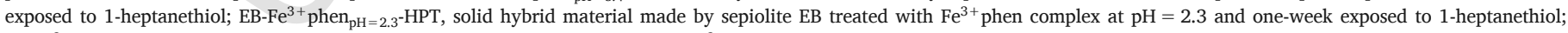

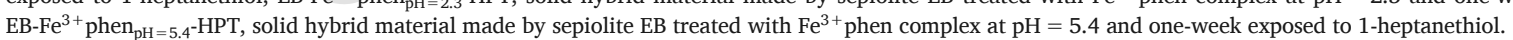

* Corresponding author.

Email address: daniele.malferrari@unimore.it (D. Malferrari) 


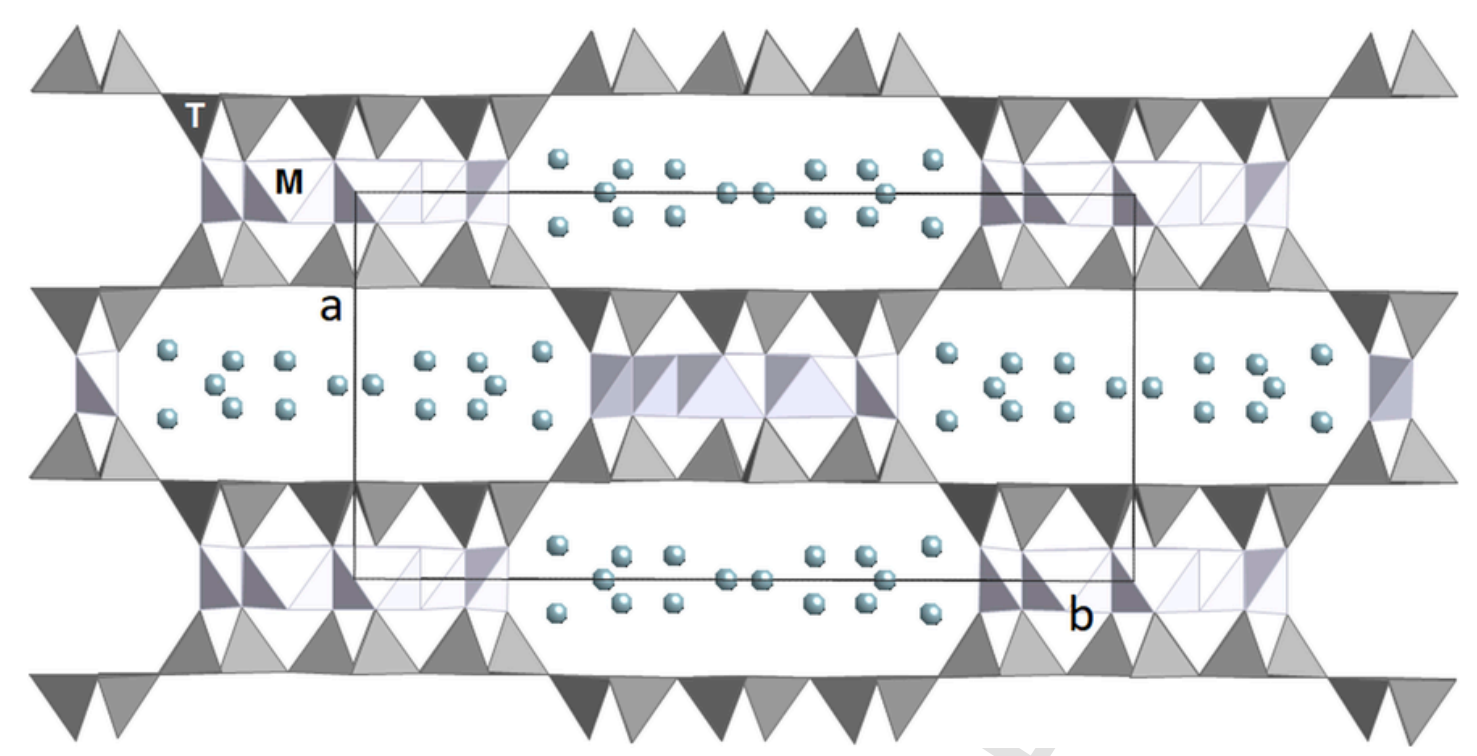

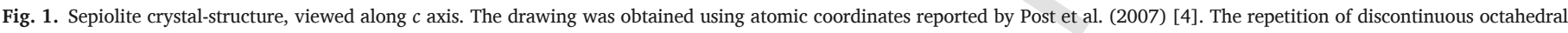
(M) and continuous tetrahedral sheets (T) creates tunnels, $c$-axis elongated, filled by weakly-bound zeolitic $\mathrm{H}_{2} \mathrm{O}$ (circles). Unit cell is outlined by continuous lines.

sion of the tetrahedra introduces additional active sites on the "external surface" of the mineral fibres [4]. OH groups on the external surface originate as a result of broken $\mathrm{Si}-\mathrm{O}-\mathrm{Si}$ bonds, balancing their residual charge by accepting a proton to form $\mathrm{Si}-\mathrm{OH}$ groups which can react with several molecules by formation of different bonding.

Due to its unique structure and specific physico-chemical properties, sepiolite is used as an adsorbent, decolorizing agent, catalyst or catalyst carrier [1,6,7] and as an inorganic membrane for ultra-filtration [8]. Furthermore sepiolite, together with palygorskite (a modulated layer silicate where tunnels measure of $3.7 \times 6.0 \AA^{2}$ in cross section) and indigo $\left(\mathrm{C}_{16} \mathrm{H}_{10} \mathrm{~N}_{2} \mathrm{O}_{2}\right)$, forms the famous Maya Blue pigment, well known in Cultural Heritage for its outstanding stability [9-11].

Owing to its strong interfacial properties, sepiolite was proposed as an adsorbent of organic and metallo-organic molecules [6,11,13-16]. Small polar molecules, such as ammonia, methanol, acetone, and ethylene glycol can be easily incorporated into the sepiolite tunnels [6,12], as well as much larger compounds like hexane, benzene, pyridine, methylene blue, indigo, and cetyltrimethylammonium bromide [14-16]. However, reactions with polar molecules can be affected by chemical substitutions in mineral structure as well as by different mineral morphology [17]. Computational studies were carried out to explain the diffusion process of organic compounds inside the sepiolite tunnels. More specifically, a molecular dynamics study $[10,11]$ and an approach based on density functional theory computation [18] indicated that indigo can be easily accommodated into the sepiolite tunnels as well as pyridine, methylene blue, and quaternary amines [19].

Some previous studies dealing with the intercalation of lamellar layered silicates, such as montmorillonite, with cationic metal complexes, specifically $\mathrm{Fe}^{3+}$ phenanthroline, showed that modifications by ion exchange reactions provide larger spacing between layers [20,21]. In these layer silicates, $\mathrm{Fe}^{3+}$-phenanthroline complex, both on external surfaces and in the interlayer, assumes a bi-dimensional disposition. Montmorillonite treated with $\mathrm{Fe}^{3+}$ phenanthroline can be used for the removal of sulfur containing phases from waste gasses [22,23], similarly to synthetic phases commonly used for the same purpose [24]. In sepiolite, hosted molecules, such as indigo, are expected to interact with water located inside structural channels due to the absence of layer charge and the needle-like morphology of the mineral, thus defining a linear rather than a bi-dimensional distribution $[10,25]$.

In this study, a new hybrid material, i.e., sepiolite functionalized with the $\mu$-oxo 1:1 $\mathrm{Fe}$-phenanthroline complex $\left[\left(\mathrm{OH}_{2}\right)_{3}(\right.$ phen $) \mathrm{Fe}-$
OFe(phen) $\left.\left(\mathrm{OH}_{2}\right)_{3}\right]\left(\mathrm{SO}_{4}\right)_{2}$ (hereafter $\mathrm{Fe}^{3+}$ phen) [26] was prepared as a novel and efficient adsorbent material to remove sulfur-bearing gases, such as 1-heptanethiol. Two sepiolite samples were considered, i.e., sepiolite from Valdemoro (Spain) and from Elbuur (Somalia) characterized by a long and by an intermediate fiber morphology, respectively. The aims of our study are 1) to prepare and characterize the sepiolite- $\mathrm{Fe}^{3+}$ phen hybrid material; 2) to investigate the effects and the mechanisms that enhance the $\mathrm{Fe}^{3+}$ phen adsorption on sepiolite; 3) to test the immobilization at room temperature of sulfur-bearing gases (1-heptanethiol was used as reference) by the new hybrid material; 4) to explain if the crystal chemical and morphological features of sepiolite affect the $\mathrm{Fe}^{3+}$ phen adsorption and 1-heptanethiol capture.

\section{EXPERIMENTAL}

\subsection{Materials}

Materials used in this work consists of:

i) Sepiolite from Elbuur mine in the Galmudug Regional State, central Somalia, $360 \mathrm{~km}$ North West from Mogadishu (hereafter referred as EB). Mineralogical and chemical features of this sample, were discussed in previous works [27-30]. Sepiolite, associated to minor content of calcite and traces of quartz and halite, were sampled at depths ranging from 40 to $300 \mathrm{~cm}$. Chemical formula is $\left(\mathrm{Si}_{11.888}\right.$ $\left.\mathrm{Al}_{0.112}\right)\left(\mathrm{Mg}_{7.313} \mathrm{Al}_{0.154} \mathrm{Fe}_{0.084}\right) \mathrm{O}_{30}(\mathrm{OH})_{4}\left(\mathrm{OH}_{2}\right)_{4} \times 8 \mathrm{H}_{2} \mathrm{O}$. The mineral is characterized by a relatively high cation exchange capacity ranging between 240 and $360 \mathrm{mmol} \mathrm{kg}^{-1}$ [29].

ii) Sepiolite Sp-1 from Valdemoro (Spain) (hereafter referred as SP1), which is a reference clay from the Source Clays Repository of The Clay Minerals Society. Chemical formula is $\mathrm{Si}_{12.16}\left(\mathrm{Mg}_{7.28} \mathrm{Al}_{0.02} \mathrm{Fe}^{3+}\right.$ $\left.0.02 \mathrm{Fe}^{2+}{ }_{0.01}\right) \mathrm{K}_{0.01} \mathrm{O}_{30}(\mathrm{OH})_{4}\left(\mathrm{OH}_{2}\right)_{4} \times 8 \mathrm{H}_{2} \mathrm{O}[31]$.

iii) $\mathrm{Fe}\left(\mathrm{NO}_{3}\right)_{3} \cdot 9 \mathrm{H}_{2} \mathrm{O}$ acetic acid (HAc, $100 \%$ ) and $\mathrm{NaOH}$ pellets $(>99 \%$ purity) are analytical grade RPE Carlo Erba reagents.

iv) 1,10-phenanthroline monohydrate (phen) and 1-heptanethiol (HPT) are from Sigma Aldrich.

\subsection{Preparation of sepiolite-Fe $\mathrm{F}^{3+}$ phenanthroline hybrid materials}

The $\mu$-oxo $\mathrm{Fe}^{3+}$ phenanthroline complex $\left(\mathrm{Fe}^{3+}\right.$ phen) was obtained at $\mathrm{pH} 5.4$ by preparing first $8 \mathrm{mM}$ phen solution in aqueous acetate buffer 
$(\mathrm{pH}=5.4) . \mathrm{Fe}\left(\mathrm{NO}_{3}\right)_{3} \cdot 9 \mathrm{H}_{2} \mathrm{O}$ salt was then slowly dissolved at room temperature in the phen solution in order to have a $8 \mathrm{mM}$ solution with respect to $\mathrm{Fe}^{3+}$ (corresponding to a $4 \mathrm{mM}$ solution of iron complex, hereafter indicated as $\mathrm{Fe}^{3+}$ phen $_{\mathrm{pH}=5.4}$ ).

The same procedure, performed however in unbuffered solution, was used to obtain the $\mathrm{Fe}^{3+}$ phen complex solution at $\mathrm{pH} 2.3$ $\left(\mathrm{Fe}^{3+}\right.$ phen $\left._{\mathrm{pH}=2.3}\right)$.

Afterwards aliquots of $50 \mathrm{mg}$ of sepiolite (SP1 or EB) were dispersed in $10 \mathrm{~mL}$ of $4 \mathrm{mM} \mathrm{Fe}{ }^{3+}$ phen $_{\mathrm{pH}}=5.4$ or $\mathrm{Fe}^{3+} \mathrm{phen}_{\mathrm{pH}=2.3}$ solutions and shaken for $24 \mathrm{~h}$ at room temperature. Solid-liquid separation was achieved via centrifugation. The same treatment was repeated three times. The separated solids were washed several times with distilled wa-

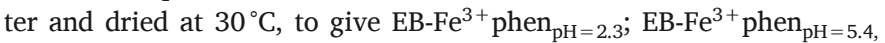
$\mathrm{SP} 1-\mathrm{Fe}^{3+}$ phen $_{\mathrm{pH}=2.3}$ and $\mathrm{SP} 1-\mathrm{Fe}^{3+}$ phen $_{\mathrm{pH}=5.4}$ hybrid materials.

UV-Vis spectrophotometric measurements on the solutions resulting after adsorption and elemental analyses of the solid samples (C, N, S) were used to quantify the amount of $\mathrm{Fe}^{3+}$ phen adsorbed by SP1 and EB in the different working conditions.

\subsection{Exposure of sepiolite-Fe ${ }^{3+}$ phenanthroline hybrid materials to HPT}

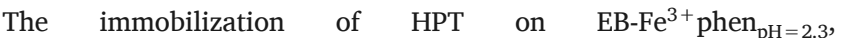
EB-Fe ${ }^{3+}$ phen $_{\mathrm{pH}=5.4}, \mathrm{SP} 1-\mathrm{Fe}^{3+}$ phen $_{\mathrm{pH}=2.3}$, and SP1- $\mathrm{Fe}^{3+}$ phen $_{\mathrm{pH}=5.4}$ was performed at $20^{\circ} \mathrm{C}$ in a closed glass box. Approximately $60 \mathrm{mg}$ of each sample were placed on the bottom of a $50 \mathrm{~mm}$ diameter glass Petri dish and put into the glass box together with a beaker containing HPT. The HPT vapor was then allowed to reach the adsorption equilibrium within the closed glass box. After one week of exposure time, obtained samples referred as $\mathrm{SP} 1-\mathrm{Fe}^{3+}$ phen $_{\mathrm{pH}=5.4}-\mathrm{HPT}$, $\mathrm{SP} 1-\mathrm{Fe}^{3+}$ phen $_{\mathrm{pH}=2.3}$-HPT, $\quad \mathrm{EB}-\mathrm{Fe}^{3+} \mathrm{phen}_{\mathrm{pH}=5.4^{-\mathrm{HPT}}, \quad \text { and }}$ $\mathrm{EB}-\mathrm{Fe}^{3+}$ phen $_{\mathrm{pH}}=2.3$-HPT were quantitatively characterized by elemental analysis and trapped HPT amounts were calculated from sulfur concentration.

\subsection{Characterization of sepiolite and sepiolite- $\mathrm{Fe}^{3+}$ phenanthroline hybrid materials before and after HTP exposure}

Several techniques were applied to characterize the materials.

$X$-ray powder diffraction (XRPD) analysis was carried out on natural sepiolite samples and after each treatment, to detect crystallographic variations on the mineral. The diffractometer used was a Philips X'Pert PRO equipped with $\mathrm{X}^{\prime}$ Celerator detector (Cu-K $\alpha$ radiation, $40 \mathrm{kV}$ and $40 \mathrm{~mA} ; 4 \leq 2 \theta \leq 20^{\circ}$, quartz as calibrating standard). The position of each peak was determined at the mid-height of the reflection, by using the software X-Pert High Score Plus.

UV-Vis measurements were recorded on a V-570 Jasco spectrophotometer. The spectrophotometer was equipped with an integrating sphere attachment (Jasco model ISN-470) and measurements were performed in the range $=220-2000 \mathrm{~nm}$, by using $\mathrm{BaSO}_{4}$ as reference.

FT-IR spectra were obtained using a JASCO FT/IR 4700 spectrophotometer (resolution: $0.4 \mathrm{~cm}-1$ ) on $\mathrm{KBr}$ pellets.

The elemental analyses (C, H, N, S) were performed on a Carlo Erba Model 1106 Elemental Analyser.

Thermogravimetric analyses (TGA) were performed on a Seiko SSC 5200 thermal analyser equipped with a quadrupole mass spectrometer (ESS, GeneSysQuadstar 422) that analyses gases evolved during thermal reactions (MSEGA). Gas sampling by the spectrometer was via an inert, fused silicon capillary system, heated to prevent gases condensing. Measurements were performed on each air-dried sample at the following experimental conditions: heating rate: $20.0^{\circ} \mathrm{C} / \mathrm{min}$; heating range: $25-1000^{\circ} \mathrm{C}$; data measurement: every $0.5 \mathrm{~s}$; purging gas: ultrapure helium, flow rate: $100 \mu \mathrm{L} / \mathrm{min}$. Gas analyses were carried out in Multiple Ion Detection mode (MID) which allows the qualitative deter- mination of evolved gasses $v s$. temperature or time checking the intensity of the signals related to the $\mathrm{m} / \mathrm{z}$ ratios 18 for $\mathrm{H}_{2} \mathrm{O}, 44$ for $\mathrm{CO}_{2}, 30$ for $\mathrm{NO}$ and $\mathrm{NO}_{2}, 34$ for $\mathrm{H}_{2} \mathrm{~S}, 46$ for $\mathrm{NO}_{2}$, and 64 for $\mathrm{SO}_{2}$ (where $\mathrm{m} / \mathrm{z}$ is the dimensionless ratio between the mass number and the charge of an ion); SEM and FARADAY detector of the spectrometer operated at $900 \mathrm{~V}$ with $1 \mathrm{~s}$ of integration time on each measured $\mathrm{m} / \mathrm{z}$ signal. To avoid differences in relative humidity, samples were equilibrated for $15 \mathrm{~min}$ inside the oven by a $100 \mu \mathrm{L} / \mathrm{min}$ flow of ultrapure helium.

NMR spectra were obtained at $300 \mathrm{~K}$ using a an AVANCE III HD 600 Bruker spectrometer equipped with a $2.5 \mathrm{~mm} \mathrm{H} / \mathrm{X}$ CPMAS probe operating at $600.13,156.38$, and $119.22 \mathrm{MHz}$ for ${ }^{1} \mathrm{H},{ }^{27} \mathrm{Al}$, and ${ }^{29} \mathrm{Si}$, respectively. Zirconia rotors of $2.5 \mathrm{~mm}$ o.d. were used and spun at the magic angle. ${ }^{1} \mathrm{H}$ NMR spectra were obtained at $33 \mathrm{kHz}$ magic angle spinning (MAS) rate, using DEPTH sequence in order to remove baseline distortions [11]. The parameters used were: $125 \mathrm{kHz}$ spectral width, $10 \mathrm{~s}$ relaxation delay, $2.4 \mu \mathrm{s} 90^{\circ}$ pulse, $4 \mathrm{k}$ data points and 32 scans. The empty rotor ${ }^{1} \mathrm{H}$ spectrum was subtracted to compensate for background effects. The cross-polarization MAS (CP-MAS) ${ }^{29} \mathrm{Si}$ NMR spectra were obtained at $8 \mathrm{KHz}$ MAS rate using the standard Bruker $\mathrm{CP}$ sequence and a $41 \mathrm{kHz}$ spectral width, $3 \mathrm{~s}$ relaxation delay, $2.4 \mu \mathrm{s} 90^{\circ}{ }^{1} \mathrm{H}$ pulse, rf field strength of about $62 \mathrm{kHz}$ for Hartmann-Hahn match, $3 \mathrm{msec}$ contact time, $4 \mathrm{k}$

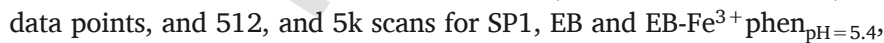
respectively.

The ${ }^{27} \mathrm{Al}$ NMR spectra were obtained at $33 \mathrm{kHz}$ MAS rates using single-pulse excitation with a $188 \mathrm{kHz}$ spectral width, $2 \mathrm{~s}$ relaxation delay, $0.5 \mu \mathrm{s} 45^{\circ}$ pulse, $4 \mathrm{k}$ data points and $4 \mathrm{k}$ scans. All chemical shifts were referenced by adjusting the spectrometer field to the value corresponding to $38.48 \mathrm{ppm}$ chemical shift for the deshielded line of the adamantane ${ }^{13} \mathrm{C}$ NMR signal, as previously reported [21]. Deconvolution of ${ }^{29} \mathrm{Si}$, ${ }^{27} \mathrm{Al}$, and ${ }^{1} \mathrm{H}$ NMR spectra was obtained with MNOVA 9.1.0 software.

\section{RESULtS}

\subsection{Elemental analysis}

Elemental analyses (Table 1) have been performed on SP1 and EB natural sepiolite samples and on $\mathrm{SP} 1-\mathrm{Fe}^{3+} \mathrm{phen}_{\mathrm{pH}=5.4}, \mathrm{SP} 1-$

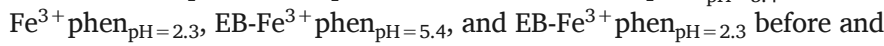
after HPT treatment.

Elemental analysis shows that $\mathrm{C}$ and $\mathrm{N}$ increase in sepiolite treated with $\mathrm{Fe}^{3+}$ phen, indicative for adsorption of the iron complex. In addition, $\mathrm{Fe}^{3+}$ phen is somewhat better adsorbed at $\mathrm{pH}$ 5.4, in particular on EB sample. The data, however, indicate that the amount of complex adsorbed by sepiolite $(0.073,0.048,0.152$, and $0.087 \mathrm{~mol} / \mathrm{Kg}$ sepiolite for $\mathrm{SP} 1-\mathrm{Fe}^{3+}$ phen $_{\mathrm{pH}=5.4}, \mathrm{SP} 1-\mathrm{Fe}^{3+}$ phen $_{\mathrm{pH}=2.3,}, \mathrm{~EB}-\mathrm{Fe}^{3+}$ phen $_{\mathrm{pH}=5.4}$,

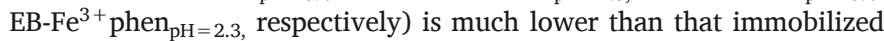
by montmorillonite $(0.434 \mathrm{~mol} / \mathrm{Kg} \mathrm{Mt})$.

Table 1

Mass percentage of the elements N, C, $\mathrm{H}$ and S for SP1 and EB natural sepiolite samples and for SP1- $\mathrm{Fe}^{3+} \mathrm{phen}_{\mathrm{pH}=5.4}, \mathrm{SP} 1-\mathrm{Fe}^{3+} \mathrm{phen}_{\mathrm{pH}=2.3}, \mathrm{~EB}-\mathrm{Fe}^{3+} \mathrm{phen}_{\mathrm{pH}}=5.4$, and $\mathrm{EB}_{-} \mathrm{Fe}^{3+} \mathrm{phen}_{\mathrm{pH}=2.3}$ before and after HPT treatment.

\begin{tabular}{|c|c|c|c|c|}
\hline Sample & N (\%) & C (\%) & $\mathrm{H}(\%)$ & S (\%) \\
\hline SP1 & 0 & 0.15 & 1.95 & 0 \\
\hline $\mathrm{EB}$ & 0 & 0.46 & 2.52 & 0 \\
\hline $\mathrm{SP} 1-\mathrm{Fe}^{3+} \mathrm{phen}_{\mathrm{pH}=5.4}$ & 0.41 & 2.05 & 1.81 & 0 \\
\hline $\mathrm{SP} 1-\mathrm{Fe}^{3+}$ phen $_{\mathrm{pH}=2.3}$ & 0.27 & 1.41 & 1.93 & 0 \\
\hline 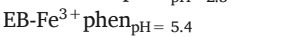 & 0.85 & 4.42 & 2.02 & 0 \\
\hline $\mathrm{EB}^{-\mathrm{Fe}^{3+}}$ phen $_{\mathrm{pH}}=2.3$ & 0.49 & 2.59 & 2.41 & 0 \\
\hline $\mathrm{SP} 1-\mathrm{Fe}^{3+} \mathrm{phen}_{\mathrm{pH}}=5.4^{-\mathrm{HPT}}$ & 0.16 & 39.18 & 9.78 & 14.88 \\
\hline $\mathrm{SP} 1-\mathrm{Fe}^{3+}$ phen $_{\mathrm{pH}=2.3^{-} \mathrm{HPT}}$ & 0.18 & 23.14 & 5.47 & 8.36 \\
\hline $\mathrm{EB}^{-\mathrm{Fe}^{3+}} \mathrm{phen}_{\mathrm{pH}}=5.4^{-\mathrm{HPT}}$ & 0.17 & 51.33 & 12.39 & 19.42 \\
\hline $\mathrm{EB}^{-\mathrm{Fe}^{3+}}$ phen $_{\mathrm{pH}}=2.3^{-\mathrm{HPT}}$ & 0.23 & 35.50 & 7.81 & 12.99 \\
\hline
\end{tabular}


The efficiency of the interaction HPT-sepiolite was assessed by measuring changes in sulfur content. The results show that sulfur amount strongly increases with the interaction time and EB sample treated at $\mathrm{pH}$ 5.4 is the most effective to reduce gaseous HPT (Table 1).

\subsection{XRD analysis}

Fig. 2a shows the X-ray diffraction patterns of the two starting sepiolites (SP1 and EB) in the $2 \theta$ range $5-30^{\circ}$. Both samples are found to be almost pure. Variation in structural ordering is a common feature in sepiolite samples of many deposits world-wide [32]. These variations can be studied through a detailed examination of the X-ray diffraction profiles.

The two diffraction tracings patterns reveal significant differences in the characteristics of diffraction reflections (i.e., in peak position, width, and relative intensity) suggesting variability both in sample crystal ordering and composition [17]. However, because of the large overlapping of reflections in the sepiolite diffraction pattern, only a few peaks can be analyzed to obtain information on the d-spacing and reflection width. The peaks that form a non-overlapping reflection are
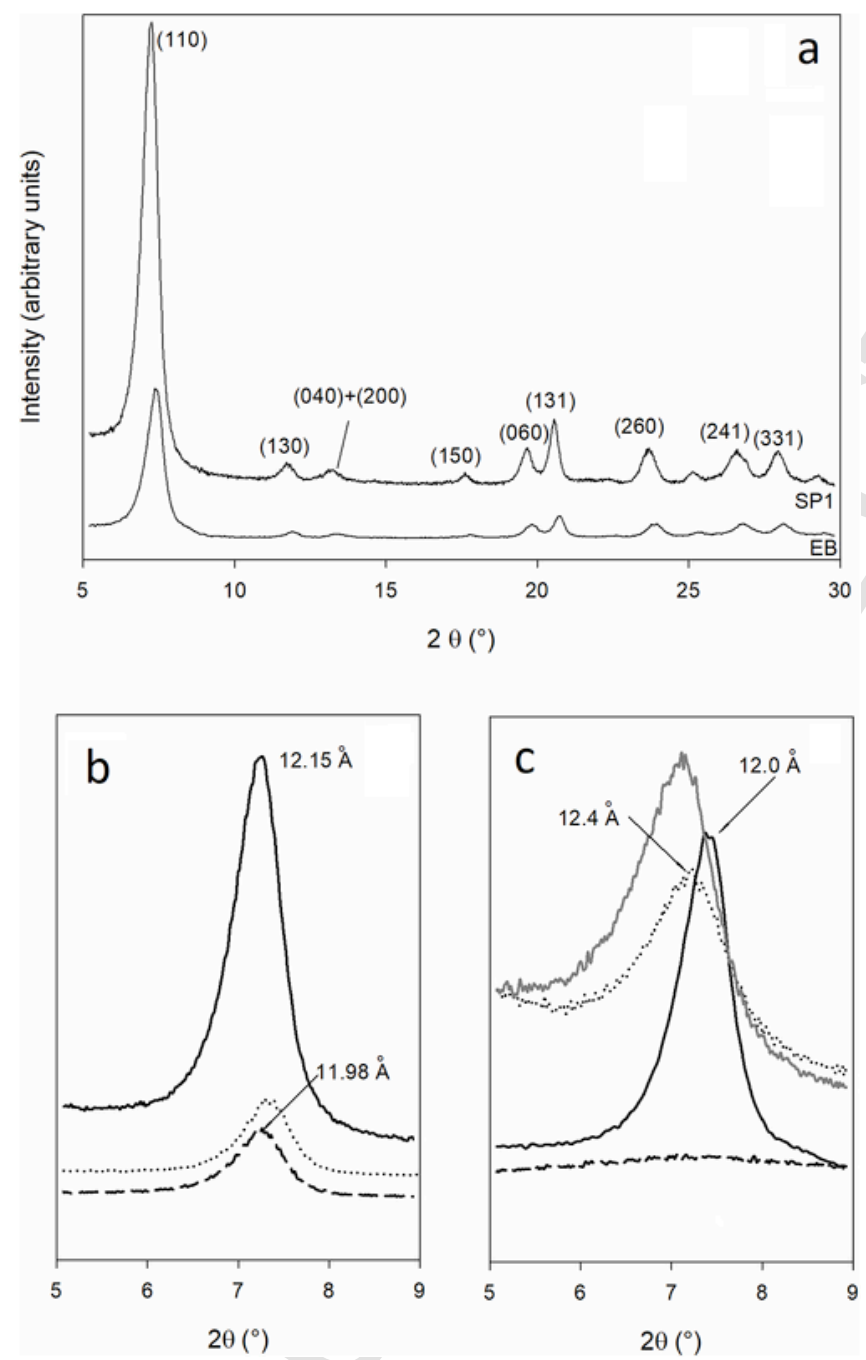

Fig. 2. Powder diffraction patterns for the sepiolite samples. a) indexed spectrum for samples SP1 and EB; b) details of (110) variation after $\mathrm{Fe}^{3+}$ phen treatment for SP1. Solid line $=\mathrm{SP} 1$ natural sample; dotted line $=\mathrm{SP} 1-\mathrm{Fe}^{3+} \mathrm{phen}_{\mathrm{pH}=5.4}$; dashed line $=\mathrm{SP} 1$ $-\mathrm{Fe}^{3+} \mathrm{phen}_{\mathrm{pH}=2.3}$; c) details of (110) variation after $\mathrm{Fe}^{3+}$ phen treatment for EB. Solid line $=\mathrm{EB}$ natural sample; dotted line $=\mathrm{EB}-\mathrm{Fe}^{3+} \mathrm{phen}_{\mathrm{pH}=5.4 ;}$ short dashed line $=\mathrm{EB}-\mathrm{Fe}^{3+} \mathrm{phen}_{\mathrm{pH}=2.3}$; solid gray line $=\mathrm{EB}$ treated at $\mathrm{pH} 2.3$ without $\mathrm{Fe}^{3+}$ phen. related to the reflections (110), (130), (131), (241), and (331). To calculate the correct position of $\mathrm{d}_{(001)}$ and its width at half maximum (WHM) the correction procedure suggested by Sanchéz del Rio et al. [17] was applied.

Note that: i) SP1 sepiolite presents (110) reflection d-values at $12.15 \AA$ whereas EB sepiolite at $12.0 \AA$; ii) all the reflections present lower intensity for EB and some of them are less defined (e.g., (130), (150)), suggesting a greater disorder in EB than in SP1.

After the treatment with $\mathrm{Fe}^{3+}$ phen some changes in (110) peak position and shape occur, mostly evident for EB sepiolite; these variations could be attributed to modifications in the cell dimensions and in crystal order, namely: i) the $\mathrm{d}_{(110)} \mathrm{SP} 1-\mathrm{Fe}^{3+}$ phen $_{\mathrm{pH}=5.4}$ and $\mathrm{d}_{(110)} \mathrm{SP} 1$ $-\mathrm{Fe}^{3+}$ phen $_{\mathrm{pH}=2.3}$ peak positions slightly decrease up to $11.98 \AA$ (Fig. $2 \mathrm{~b})$; ii) the WHM of $\mathrm{d}_{(110)} \mathrm{SP} 1-\mathrm{Fe}^{3+}$ phen $_{\mathrm{pH}=5.4}$ and of $\mathrm{d}_{(110)} \mathrm{SP} 1-$ $\mathrm{Fe}^{3+}$ phen $_{\mathrm{pH}=2.3}$ slightly increase from 0.62 (untreated sepiolite) to 0.64 and 0.65 , respectively (Fig. 2a and b); iii) the $\mathrm{d}_{(110)}$ peak position of $\mathrm{EB}^{-\mathrm{Fe}^{3+}}$ phen $_{\mathrm{pH}=5.4}$ increases at $12.40 \AA$ and WHM increases from 0.68 (EB, natural sepiolite) to 0.99 . For EB-Fe ${ }^{3+} \mathrm{phen}_{\mathrm{pH}=2.3}$ sample, the (001) reflection completely disappears and a new broad band appears in the $2 \theta$ range $20-25^{\circ}$. To evaluate if this behavior can be related only to the acid $\mathrm{pH}$ value, the diffraction pattern of $\mathrm{EB}$ sample treated at $\mathrm{pH}=2.3$ without $\mathrm{Fe}^{3+}$ phen was collected. The result (Fig. 2c) shows evident peaks $\left(\mathrm{WHM} \mathrm{d}_{(001)}=1.06, \mathrm{~d}_{(110)}=12.40 \AA\right.$ ) and, consequently, acidic $\mathrm{pH}$ is not the only responsible for the damage of the crystalline order. Therefore, as already reported in literature [33], the modifications introduced by treatments also depend on the crystallographic features of the pristine sepiolite.

X-ray diffraction spectra obtained for samples after the HTP exposure do not indicate any further variations with respect to former samples.

\subsection{DR UV-Vis measurements}

The UV-Vis spectra of $\mathrm{Fe}^{3+}$ phen in solution, obtained at different concentrations, were reported by Bernini et al. [20-22]. $\mathrm{Fe}^{3+}$ phen spectrum is characterized by a charge transfer band $\left(\mathrm{O}^{2-}\right.$ (bridge $) \rightarrow \mathrm{Fe}^{3+}$ charge-transfer transition) at $\lambda=356 \mathrm{~nm}$ and two additional bands at 223 and $266 \mathrm{~nm}$ attributable to the aromatic ligand. In $\mathrm{Fe}^{2+}$ phen spectrum, the band at $\lambda=356 \mathrm{~nm}$ is replaced by a band with a maximum at $\lambda=510 \mathrm{~nm}$ (attributable to a $\mathrm{d} \rightarrow \pi^{*}$ metal to ligand charge transfer transition) and two shoulders at $\lambda=455$ and $493 \mathrm{~nm}$ [34]. The signals observed at about 356 and $510 \mathrm{~nm}$ will therefore be indicative of the presence of a phenanthroline complex of $\mathrm{Fe}^{3+}$ and $\mathrm{Fe}^{2+}$, respectively. In order to confirm the interaction of $\mathrm{Fe}^{3+}$ phen with sepiolite EB and SP1 at different $\mathrm{pH}$ values, the UV-Vis spectra of SP1 and EB natural samples were compared with spectra obtained for $\mathrm{SP} 1-\mathrm{Fe}^{3+}$ phen ${ }_{\mathrm{pH}}=5.4$, $\mathrm{SP} 1-\mathrm{Fe}^{3+}$ phen $_{\mathrm{pH}=2.3}$, EB-Fe ${ }^{3+}$ phen ${ }_{\mathrm{pH}=5.4}$, and $\mathrm{EB} \mathrm{Fe}^{3+}$ phen ${ }_{\mathrm{pH}=2.3}$ as shown in Fig. 3. Samples SP1 and EB both display two absorbance peaks at $\lambda=210$ and $250 \mathrm{~nm}$ due to electronic transitions of the mineral. After treatment with $\mathrm{Fe}^{3+}$ phen all samples show a broadening and an overall increase in the region from $\lambda=200-400 \mathrm{~nm}$. This increase can be associated to the presence of peaks related to the $\mathrm{Fe}^{3+}$ phen complex. In particular the broad band with maximum at $\lambda=324 \mathrm{~nm}$ can be assigned to the above mentioned $\mathrm{O}^{2-}$ (bridge) $\rightarrow \mathrm{Fe}^{3+}$ charge-transfer transition, typical for the ferric form of the complex. All the spectra of sepiolite samples treated with $\mathrm{Fe}^{3+}$ phen and exposed to HPT show a composite band with the maximum at $\lambda=518 \mathrm{~nm}$, also observed for $\mathrm{Fe}^{2+}$-phenanthroline complex in solution [22]. Also in this case, the signal corresponds to the $\mathrm{d} \rightarrow \pi^{*}$ metal-to-ligand charge transfer band of the $\mathrm{Fe}^{2+}$-phenanthroline complex. Furthermore, the band with maximum at $\lambda=324 \mathrm{~nm}$ is no longer present in samples treated at $\mathrm{pH}=2.3$ and exposed to HPT, suggesting a complete $\mathrm{Fe}^{3+} \rightarrow \mathrm{Fe}^{2+}$ reduction. For $\mathrm{EB}^{-\mathrm{Fe}^{3+}}$ phen $_{\mathrm{pH}=5.4}$, instead, a residual broad band at about $\lambda=324 \mathrm{~nm}$ is still present. 

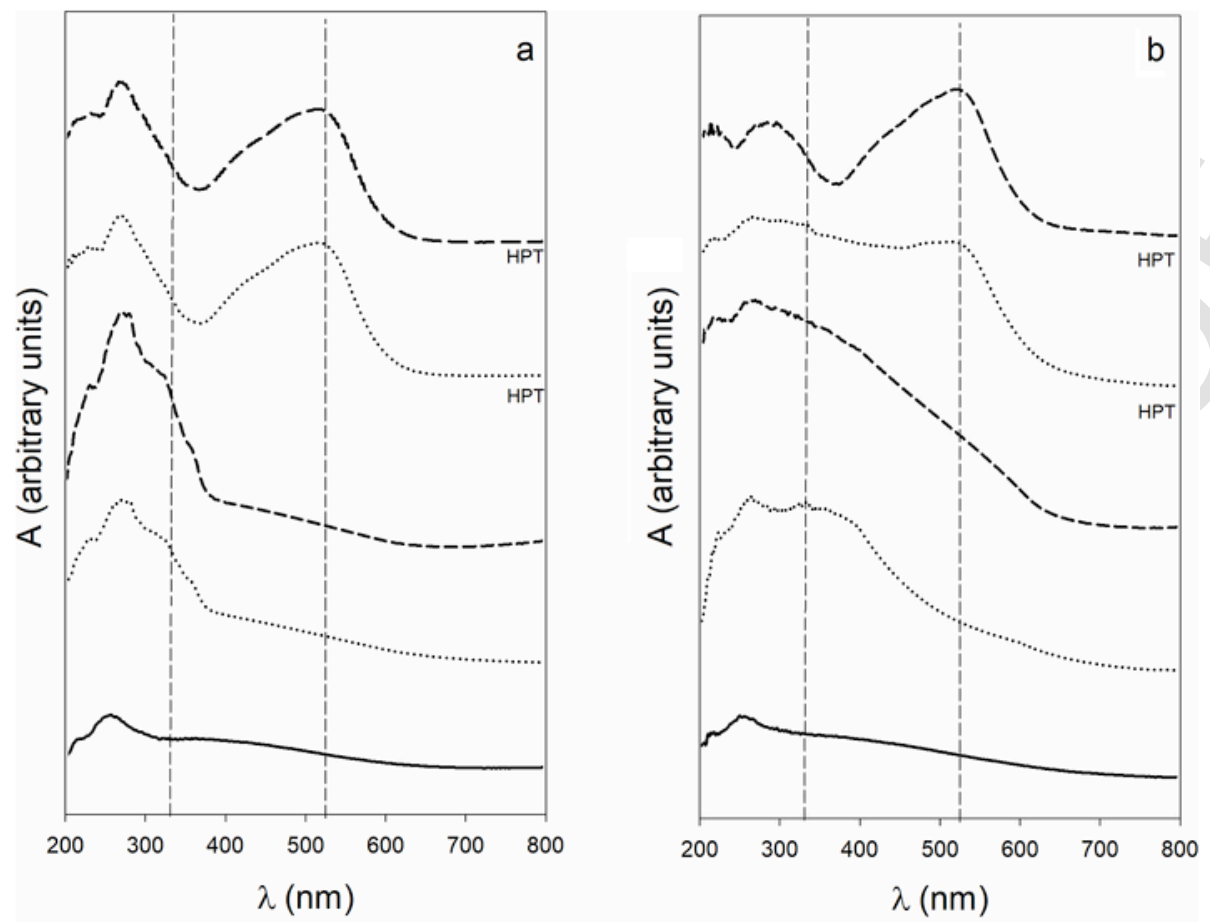

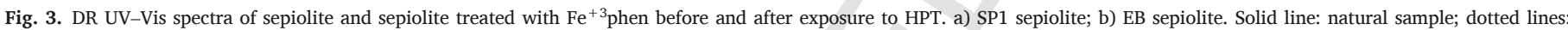

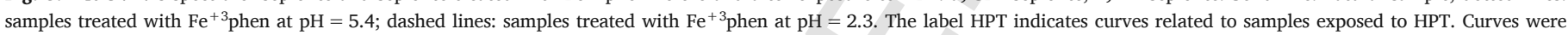
shifted on y axis for sake of clarity.

\subsection{FT-IR measurements}

The FTIR spectra of natural sepiolite samples and of sepiolite- $\mathrm{Fe}^{3+}$ phen hybrid materials before and after exposure to HPT are shown in Fig. 4. Some characteristic sepiolite bands are observed in the hydroxyl-stretching region: i) two bands at 3689 and $3620 \mathrm{~cm}^{-1}$ which are associated to the symmetric stretching vibration of the $\mathrm{OH}$ groups coordinated with $\mathrm{Mg}^{2+}$; ii) a band at $3568 \mathrm{~cm}^{-1}$ related to the stretching modes of $\mathrm{H}_{2} \mathrm{O}$ molecules coordinated with octahedral $\mathrm{Mg}^{2+}$ cations on the channel edge; iii) two broad bands at 3363 and $3253 \mathrm{~cm}^{-1}$ that are attributed to $\mathrm{OH}$ stretching vibration of differently sited zeolitic water molecules along structural channels $[35,36]$. The two bands at 1667 and $1619 \mathrm{~cm}^{-1}$ can be assigned to zeolitic and adsorbed water,
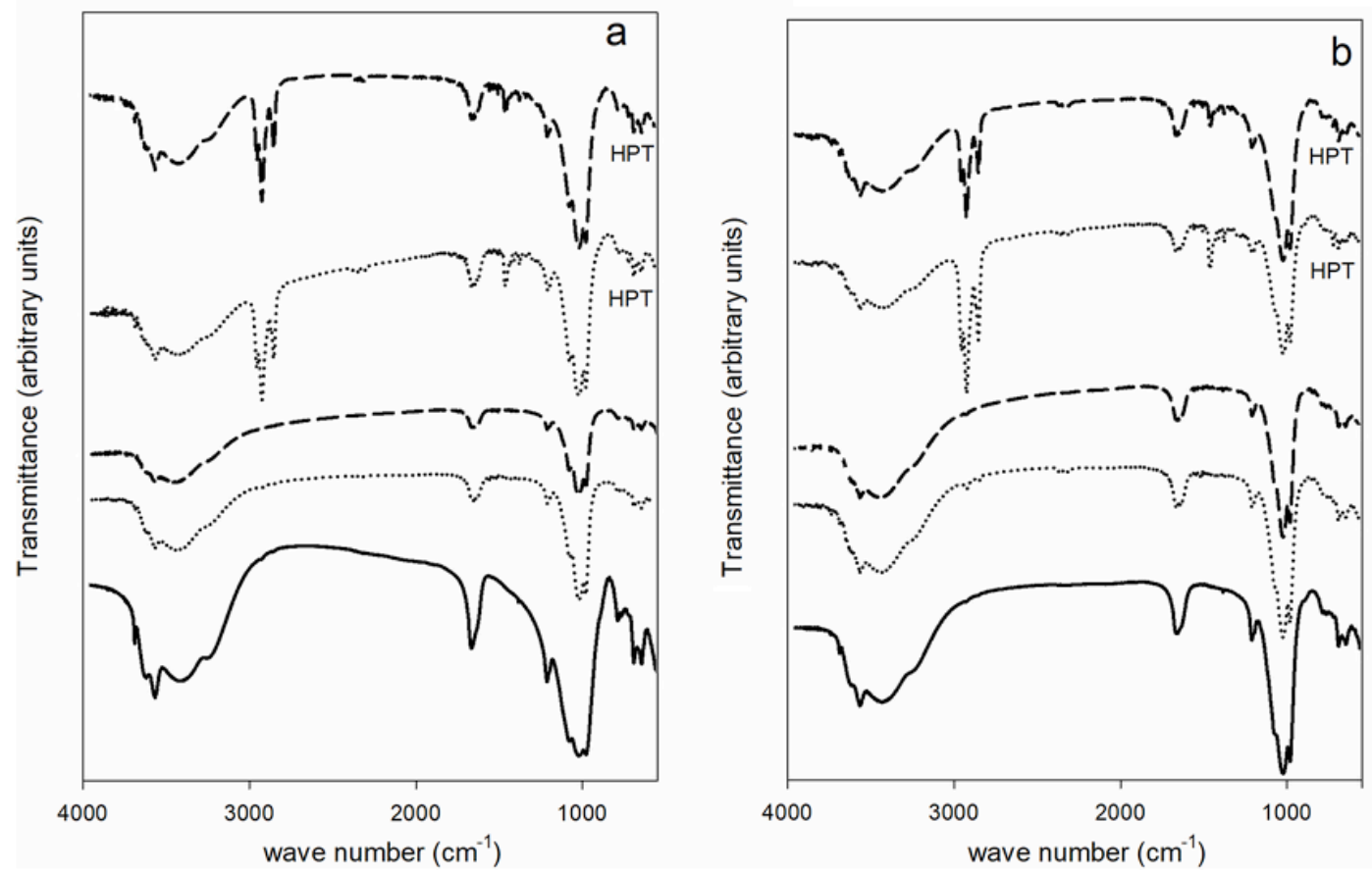

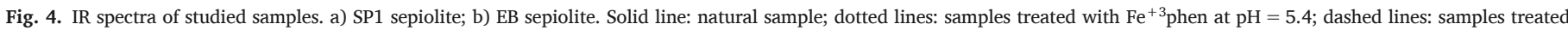
with $\mathrm{Fe}^{+3} \mathrm{phen}$ at $\mathrm{pH}=2.3$. The label HPT indicates curves related to samples exposed to HTP. Curves were shifted on y axis for sake of clarity. 
respectively [37]. Bands in the $1200-400 \mathrm{~cm}^{-1}$ range represent the lattice vibrations of sepiolite, i.e., the bands of $\mathrm{Si}-\mathrm{O}-\mathrm{Si}$ stretching occur at $1021 \mathrm{~cm}^{-1}$, the band at $979 \mathrm{~cm}^{-1}$ forms as a result of stretching vibration of $\mathrm{Si}-\mathrm{O}-\mathrm{Si}$ bonds connected by non-linear bridge oxygen [38], whereas the band at $956 \mathrm{~cm}^{-1}$ is related to terminal $\mathrm{Si}-\mathrm{OH}$ deformation. Effects at 486 and $503 \mathrm{~cm}^{-1}$ (shoulder) can be attributed to an $\mathrm{O}-$ $\mathrm{Si}-\mathrm{O}$ bending, whereas those at 643 and $691 \mathrm{~cm}^{-1}$ result from $\mathrm{Mg}-$ $\mathrm{OH}$ bending mode vibrations. For EB sample the bands at 3689 and at $3619 \mathrm{~cm}^{-1}$ appear less enhanced. This behavior can suggest octahedral substitutions and/or vacancies [36].

In the IR spectra obtained after the immobilization of $\mathrm{Fe}^{3+}$ phen complex $\left(\mathrm{SP} 1-\mathrm{Fe}^{3+}\right.$ phen $_{\mathrm{pH}=5.4} \mathrm{SP} 1-\mathrm{Fe}^{3+}$ phen $_{\mathrm{pH}=2.3}, \mathrm{~EB}-\mathrm{Fe}^{3+}{ }_{\mathrm{phen}} \mathrm{pH}_{\mathbf{p}}$.4 and $\mathrm{EB}-\mathrm{Fe}^{3+}$ phen $_{\mathrm{pH}=2.3}$ ) the following changes are observed: i) a broad shoulder in the $3200-2900 \mathrm{~cm}^{-1}$ range, more evident in

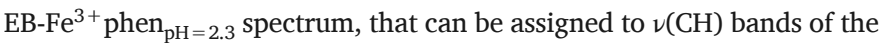
phenanthroline moieties; ii) a decrease in the adsorption bands in the $4000-3000 \mathrm{~cm}^{-1}$ range, probably suggesting that some water molecules leave partially the sepiolite structure after $\mathrm{Fe}^{3+}$ phen addition. This feature could also suggest structural variation of sepiolite or that $\mathrm{Fe}^{3+}$ phen molecules replace some water molecules coordinated to $\mathrm{Mg}^{2+}$; iii) the band at $1212 \mathrm{~cm}^{-1}$ and the shoulder at $1194 \mathrm{~cm}^{-1}$, that indicate changes in sepiolite structural order [39], do not show evident changes with respect to those observed for untreated sample; v) the OH bending effect at $1654 \mathrm{~cm}^{-1}$ decreases its intensity, probably suggesting changes in zeolitic-water bonding.

Analyzing comparatively the spectra of the samples after HPT exposition the following changes are observed: i) four new bands at 2955, 2926, 2871, and $2855 \mathrm{~cm}^{-1}$ which can be related to $\mathrm{C}-\mathrm{H}$ stretching of heptanethiol interacting with $\mathrm{Fe}^{3+}$ phen treated sepiolite. The bands at 2871 and $2855 \mathrm{~cm}^{-1}$ can be assigned to the symmetric stretching vibrations of $\mathrm{CH}_{3}$ and $\mathrm{CH}_{2}$, whereas those at 2955 and $2926 \mathrm{~cm}^{-1}$ to the antisymmetric stretching vibrations of $\mathrm{CH}_{3}$ and $\mathrm{CH}_{2}$ groups, respectively $[40,41]$; weak bending signals of heptanethiol can be observed: the scissoring of $\mathrm{CH}_{2}$ at about $1465 \mathrm{~cm}^{-1}$, the antisymmetric and symmetric bending of $\mathrm{CH}_{3}$ at 1457 and at $1378 \mathrm{~cm}^{-1}$, respectively; ii) the transmittance of the band in the $4000-3000 \mathrm{~cm}^{-1}$ range decreases, suggesting the water molecules leave partially the sepiolite structure.

No band associated with the $\mathrm{S}-\mathrm{H}$ stretching vibration (sharp and weak signals at $2550-2600 \mathrm{~cm}^{-1}$ ) is observed.

\subsection{Thermal analysis}

Thermogravimetric analyses (TGA) together with the derivative signal (DTGA) are shown in Fig. 5.

The thermal behavior of natural sepiolite samples is here briefly summarized. In the temperature range $30-600^{\circ} \mathrm{C}$, both samples indicate three distinct weight loss steps with maxima below $100^{\circ} \mathrm{C}\left(\mathrm{SP} 1=93^{\circ} \mathrm{C}\right.$; $\left.\mathrm{EB}=80^{\circ} \mathrm{C}\right)$, between 250 and $350^{\circ} \mathrm{C}\left(\mathrm{SP} 1=315^{\circ} \mathrm{C}\right.$; $\left.\mathrm{EB}=302{ }^{\circ} \mathrm{C}\right)$, and between 350 and $600^{\circ} \mathrm{C}\left(\mathrm{SP} 1=535^{\circ} \mathrm{C} ; \mathrm{EB}=513^{\circ} \mathrm{C}\right)$. The first endothermic effect with mass loss (wt\%) of $11.90 \%$ (SP1) and $10.07 \%$ (EB) is due to the loss of hygroscopic and zeolitic $\mathrm{H}_{2} \mathrm{O}$; the second peak with mass loss of $3.18 \%$ (SP1) and $3.74 \%$ (EB) is due to the loss of part of the structural $\mathrm{H}_{2} \mathrm{O}$. The release of structural $\mathrm{H}_{2} \mathrm{O}$ continues up to $600^{\circ} \mathrm{C}$ (wt $\%$ : $\mathrm{SP} 1=2.49 \%$; $\mathrm{EB}=3.28 \%$ ). After the second dehydration step the complete collapse of sepiolite channels occurs $[4,14]$. At higher temperature values SP1 shows a well-defined effect at $835^{\circ} \mathrm{C}(\mathrm{wt} \%=2.35)$ whereas sample EB evidences three broad effects at about 737,797 , and $815^{\circ} \mathrm{C}$ (overall $\mathrm{wt} \%=4.30$ ). This different behavior can be possibly associated either to tetrahedral and octahedral substitutions that are more frequent in EB sample with respect to SP1 sample, or to the different morphology with EB showing greater variability in fibres dimensions with respect to the larger and more regular ones observed in SP1, as indicated in literature [17] and confirmed by our XRPD data. These endothermic re- actions, related to dehydroxylation, transform sepiolite into the amorphous phase meta-sepiolite [42]. The exothermic peak at 843 and $822^{\circ} \mathrm{C}$ in SP1 and EB, respectively (observed in differential thermal curves and not graphically reported here), is attributed to the re-crystallization of the dehydroxylated phase and to the formation of enstatite $\left(\mathrm{MgSiO}_{3}\right)$. The evolved gas during thermal analysis (MSEGA), are all related to the dehydration or dehydoxylation relations (release of $\mathrm{H}_{2} \mathrm{O}, \mathrm{m} / z=18$, Figs. 6 and 7).

In the thermal range $25-600^{\circ} \mathrm{C}$, the DTGA (Fig. 5a and b) and MSEGA (Figs. 6 and 7) curves of $\mathrm{SP} 1-\mathrm{Fe}^{3+} \mathrm{phen}_{\mathrm{pH}=5.4}, \mathrm{SP} 1-$ $\mathrm{Fe}^{3+}$ phen $_{\mathrm{pH}=2.3}, \mathrm{~EB}^{-\mathrm{Fe}^{3+}}$ phen $_{\mathrm{pH}=5.4}$, and $\mathrm{EB}-\mathrm{Fe}^{3+} \mathrm{phen}_{\mathrm{pH}=2.3}$ show: i) a well-defined thermal reaction at about $65^{\circ} \mathrm{C}$, related to $\mathrm{H}_{2} \mathrm{O}$ release only $(m / z=18)$, associated with a weight loss much lower than in pristine sepiolite $\quad\left(\mathrm{SP} 1-\mathrm{Fe}^{3+}\right.$ phen $_{\mathrm{pH}=5.4}=6.18 \mathrm{wt} \%, \quad \mathrm{SP} 1-$ $\mathrm{Fe}^{3+}$ phen $_{\mathrm{pH}=2.3}=3.85 \mathrm{wt} \%, \quad \mathrm{~EB}-\mathrm{Fe}^{3+}{ }^{\mathrm{phen}} \mathrm{pH}=5.4=3.83 \mathrm{wt} \%, \quad$ and $\mathrm{EB}-\mathrm{Fe}^{3+}$ phen $_{\mathrm{pH}=2.3}=2.21 \mathrm{wt} \%$ ); ii) a reaction at about $270{ }^{\circ} \mathrm{C}$, more precisely: $\quad \mathrm{SP} 1-\mathrm{Fe}^{3+} \mathrm{phen}_{\mathrm{pH}=5.4}=295^{\circ} \mathrm{C} \quad(\mathrm{wt} \%=4.03), \quad \mathrm{SP} 1-$ $\mathrm{Fe}^{3+}$ phen $_{\mathrm{pH}=2.3}=281^{\circ} \mathrm{C} \quad(\mathrm{wt} \%=3.78), \quad \mathrm{EB}^{\circ} \mathrm{Fe}^{3+} \mathrm{phen}_{\mathrm{pH}=5.4}=263^{\circ} \mathrm{C}$ ( $w \mathrm{t} \%=5.06$ ), and $\mathrm{EB}-\mathrm{Fe}^{3+} \mathrm{phen}_{\mathrm{pH}=2.3}=265^{\circ} \mathrm{C}$ ( wt $\%=4.27$ ), which is related to the release of $\mathrm{H}_{2} \mathrm{O}(\mathrm{m} / z=18)$ and NO $(\mathrm{m} / z=30)$; iii) an effect with maximum in the temperature range between 440 and $480{ }^{\circ} \mathrm{C}$ $\left(\mathrm{SP} 1-\mathrm{Fe}^{3+}\right.$ phen $_{\mathrm{pH}=5.4}=448^{\circ} \mathrm{C} \quad(\mathrm{wt} \%=5.45 .19), \quad \mathrm{SP} 1-$ $\mathrm{Fe}^{3+}$ phen $_{\mathrm{pH}=2.3}=446^{\circ} \mathrm{C} \quad(\mathrm{wt} \%=4.91), \quad \mathrm{EB}^{\circ}-\mathrm{Fe}^{3+} \mathrm{phen}_{\mathrm{pH}=5.4}=472^{\circ} \mathrm{C}$ ( $\mathrm{wt} \%=7.51$ ), and $\mathrm{EB}-\mathrm{Fe}^{3+} \mathrm{phen}_{\mathrm{pH}=2.3}=474^{\circ} \mathrm{C}$ ( $\left.\mathrm{wt} \%=7.16\right)$ mostly associated to the release of $\mathrm{NO}(\mathrm{m} / \mathrm{z}=30)$ and $\mathrm{CO}_{2}(\mathrm{~m} / \mathrm{z}=44)$ and by residual $\mathrm{H}_{2} \mathrm{O}$ molecules $(m / z=18)$; iv) in the temperature range between 600 and $1000{ }^{\circ} \mathrm{C}$ in $\mathrm{SP} 1-\mathrm{Fe}^{3+} \mathrm{phen}_{\mathrm{pH}=5.4}$ and $\mathrm{SP} 1-$ $\mathrm{Fe}^{3+}$ phen $_{\mathrm{pH}=2.3}$ the band observed at $835^{\circ} \mathrm{C}$ in pristine sepiolite enlarge and the maximum shifts at about $770^{\circ} \mathrm{C}$ (SP1$\mathrm{Fe}^{3+}$ phen $_{\mathrm{pH}=5.4}=5.18 \mathrm{wt} \%$; SP $1-\mathrm{Fe}^{3+}$ phen $\left._{\mathrm{pH}=2.3}=5.38 \mathrm{wt} \%\right)$ and is associated to $\mathrm{H}_{2} \mathrm{O}(\mathrm{m} / \mathrm{z}=18)$, $\mathrm{NO}(\mathrm{m} / \mathrm{z}=30)$, and $\mathrm{CO}_{2}(\mathrm{~m} / \mathrm{z}=44)$ release; v) $\mathrm{EB}^{-\mathrm{Fe}^{3+}} \mathrm{phen}_{\mathrm{pH}=5.4}$ and $\mathrm{EB}-\mathrm{Fe}^{3+} \mathrm{phen}_{\mathrm{pH}=2.3}$ show a well-defined peak at $\mathrm{T}=680^{\circ} \mathrm{C} \quad\left(\mathrm{EB}^{-\mathrm{Fe}^{3+}} \mathrm{phen}_{\mathrm{pH}=5.4}=7.11 \mathrm{wt} \%\right.$;

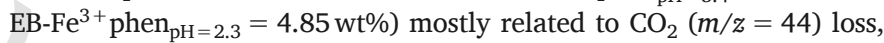
and two broad effects between 720 and $1000{ }^{\circ} \mathrm{C}$ characterized by

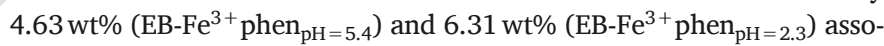
ciated with $\mathrm{H}_{2} \mathrm{O}(\mathrm{m} / \mathrm{z}=18)$, $\mathrm{NO}(\mathrm{m} / \mathrm{z}=30)$, and $\mathrm{CO}_{2}(\mathrm{~m} / \mathrm{z}=44)$ release.

After the HPT exposure the overall weight loss strongly increases for all samples $\left(\mathrm{SP} 1-\mathrm{Fe}^{3+} \mathrm{phen}_{\mathrm{pH}=5.4}=64.12 \mathrm{wt} \%\right.$; SP1$\mathrm{Fe}^{3+}$ phen $_{\mathrm{pH}=2.3}=47.3 \mathrm{wt} \% ; \quad \mathrm{EB}_{-} \mathrm{Fe}^{3+}$ phen $_{\mathrm{pH}=5.4}=62.5 \mathrm{wt} \%$, and EB-Fe ${ }^{3+}$ phen $_{\mathrm{pH}=2.3}=50.0 \mathrm{wt} \%$ ), being mostly related to $\mathrm{SO}_{2}$ release at about $200^{\circ} \mathrm{C}$ (Figs. 6 and 7).

No release of $\mathrm{H}_{2} \mathrm{~S}(\mathrm{~m} / \mathrm{z}=34)$ and $\mathrm{NO}_{2}(\mathrm{~m} / \mathrm{z}=46)$ was observed in the investigated thermal range.

\subsection{NMR analysis}

Fig. 8 compares the CP-MAS ${ }^{29} \mathrm{Si}$ NMR spectra of samples SP1 and EB. Three major signals at $-97.2,-94.2$, and $-91.7 \mathrm{ppm}$, corresponding to type 1 (edge), 3 (centre), and 2 (near edge) Si sites, respectively, are present [25]. A fourth resonance at $-85.2 \mathrm{ppm}$, low in SP1, is clearly detected in EB sepiolite sample. It has been assigned to $\mathrm{Q}^{2}{ }^{29} \mathrm{Si}-\mathrm{OH}$ nuclei [43] and indicates the presence of a higher number of these sites in $\mathrm{EB}$ with respect to SP1.

Moreover, ${ }^{29} \mathrm{Si}$ signals are broader in EB and deconvolution shows that this broadness could be due to a broad component at about $-96 \mathrm{ppm}$ (Fig. SM1). This points to a certain distortion of the structure of EB sepiolite with respect to SP1.

The ${ }^{27} \mathrm{Al}$ NMR spectra of EB and SP1 are reported in Fig. 9 and are quite different. In SP1 the majority of $\mathrm{Al}^{3+}$ ions are found in octahedral sites, and only about $25 \%$ in tetrahedral ones, whereas in EB 2:3 $\mathrm{Al}^{3+}$ ions are found in tetrahedral sites (Fig. SM2). Two of them are distinguished at 67.7 and $58.9 \mathrm{ppm}$ and the former is absent in SP1. 

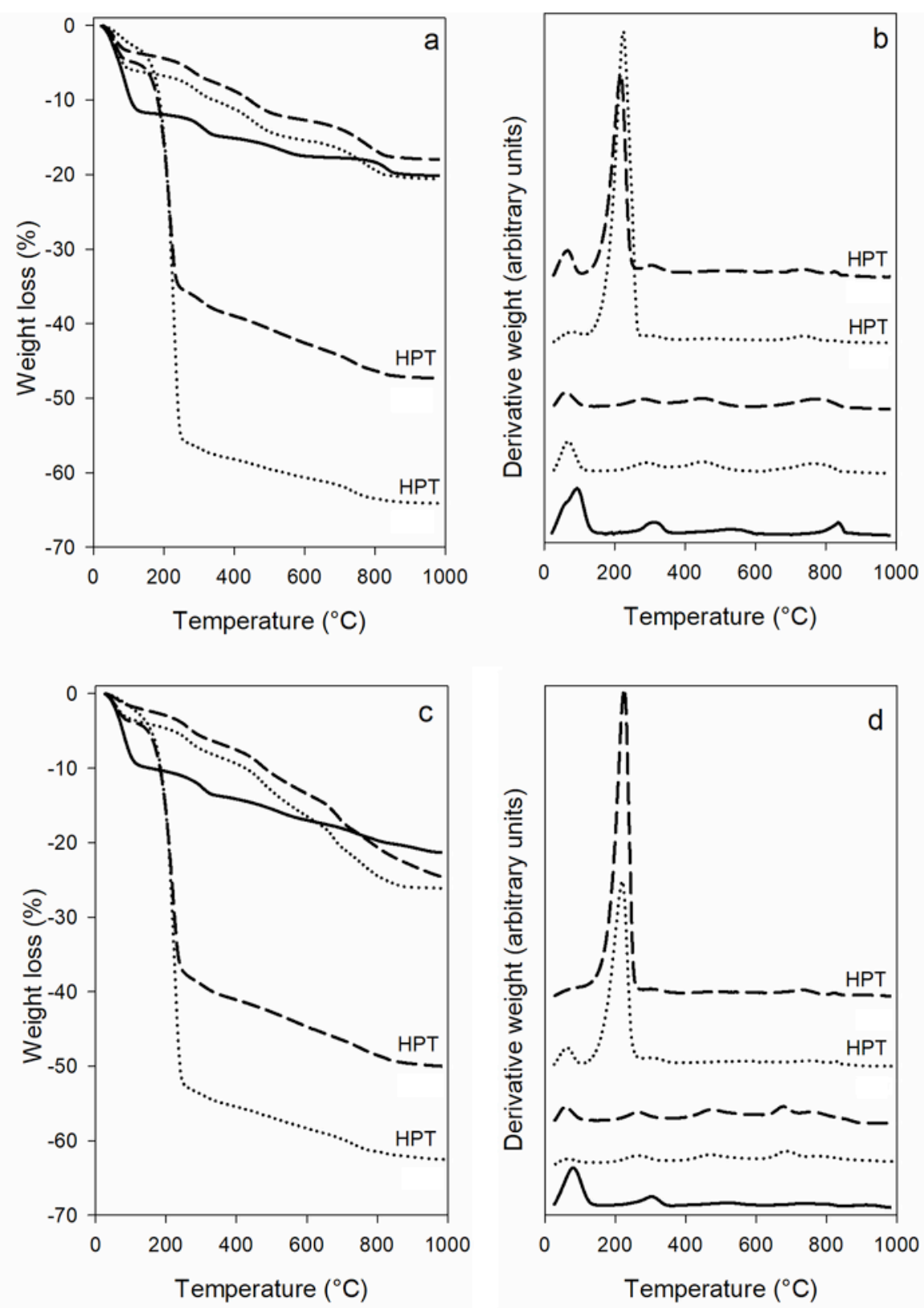

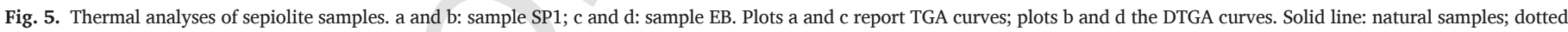

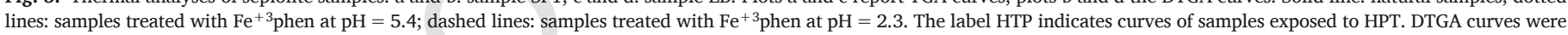
shifted on y axis for sake of clarity.

The deshielded chemical shift of this signal can be related to a distortion of the corresponding $\mathrm{O}-\mathrm{Al}-\mathrm{O}$ bond angles (the higher the bond angle the higher the chemical shift) [44]. ${ }^{29} \mathrm{Si}$ and ${ }^{27} \mathrm{Al}$ data are resumed in Table 2.

\section{DISCUSSION}

The interaction of $\mathrm{Fe}^{3+}$ phen with sepiolite is influenced by the mineral crystal order. SP1 shows a higher crystal order than EB, as demonstrated by narrower peaks in the X-ray spectra. When treated with $\mathrm{Fe}^{3+}$ phen, the two samples show different binding efficiency, with EB demonstrating a significant higher adsorption capacity at the same treatment conditions. Adsorption is also favored in both samples at $\mathrm{pH}$ 5.4 when compared to $\mathrm{pH}$ 2.3. At this lower $\mathrm{pH}$ value long-range struc- tural order of EB sample is strongly compromised, as demonstrated by the absence of peaks in XRD spectra.

Treatment with $\mathrm{Fe}^{3+}$ phen reduces the amount of hygroscopic and zeolitic water in both samples. For natural SP1 and EB samples, thermogravimetric analyses show water release below $100^{\circ} \mathrm{C}$ of 11.9 and $10.07 \mathrm{wt} \%$, respectively. After $\mathrm{Fe}^{3+}$ phen treatment, this process is observed at lower temperature and is associated to a decrease of the weight loss amount, i.e. 3.85 and $2.21 \mathrm{wt} \%$ at $\mathrm{pH} 2.3$ and 6.18 and $3.83 \mathrm{wt} \%$ at pH 5.4 for SP1 and EB, respectively. All these data suggest that a more efficient adsorption process is associated to a lowering in hygroscopic and zeolitic water content present in the treated sample. The decrease of hygroscopic and zeolitic water following $\mathrm{Fe}^{3+}$ phen treatment is also confirmed by NMR data, revealing also an effect over the feature associated to $\mathrm{Mg}-\mathrm{OH}$ and $\mathrm{Si}-\mathrm{OH}$ moieties (Figs. SM3-SM5). 

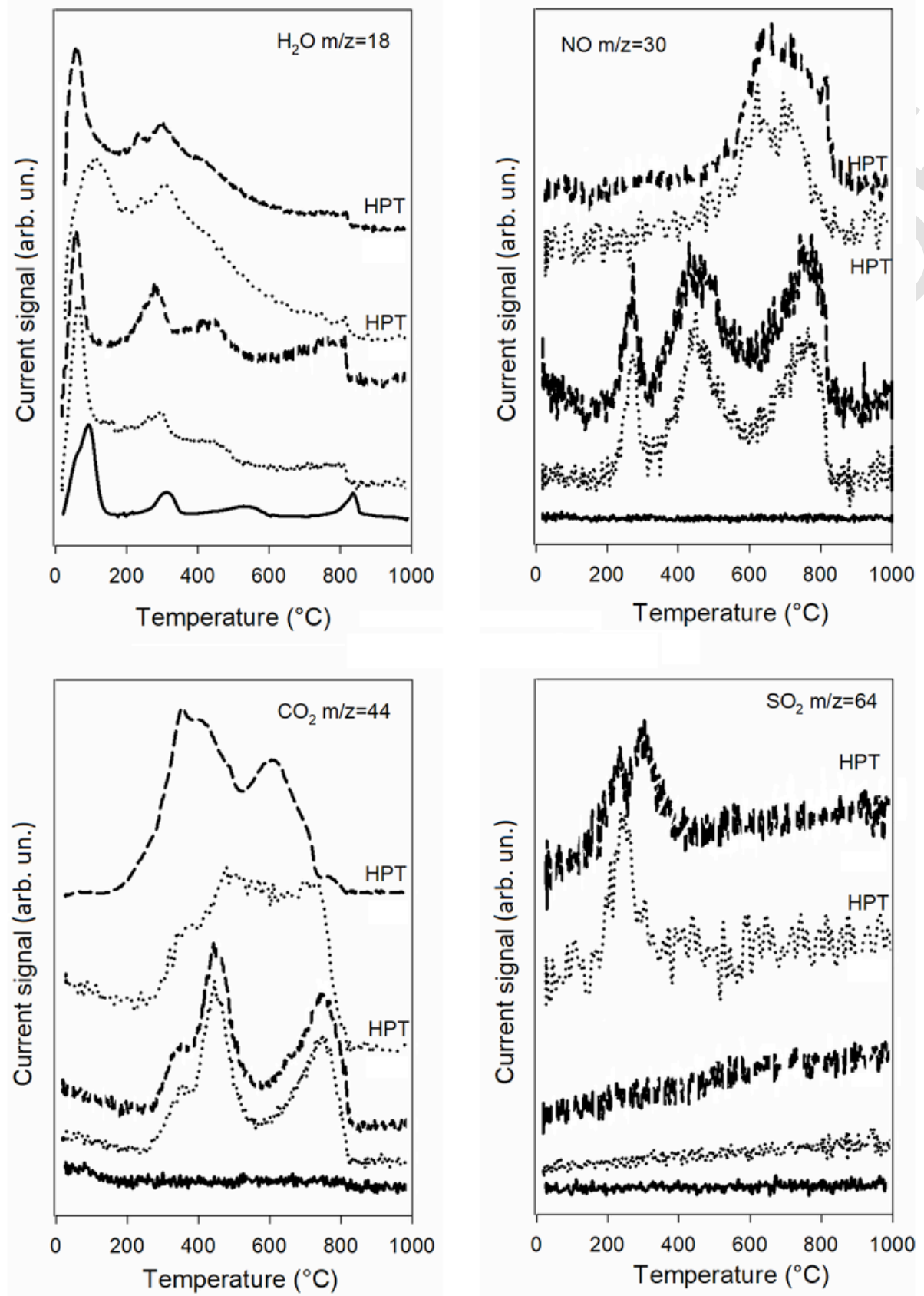

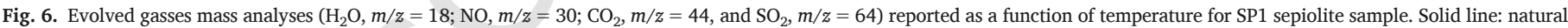

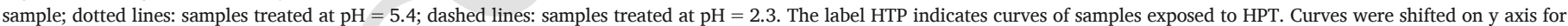
sake of clarity.

IR spectra (Fig. 4 and SM7) show a variation at $3688 \mathrm{~cm}^{-1}$ in $\mathrm{Fe}^{3+}$ phen-treated samples. This modification can be attributed to the $\mathrm{OH}$ groups involved in the $\mathrm{Mg}^{2+}-\mathrm{OH}$ symmetric stretching vibrations [45]. All these data are consistent with $\mathrm{Fe}^{3+}$ phen location not only on the external surface of the mineral, but also on the channels hosting zeolitic water. In this case, the $\mathrm{Fe}^{3+}$ phen aromatic rings within sepiolite channels should be very close to the structural hydroxyl protons of sepiolite, as also inferred from NMR results (Fig. SM3).

As already found for montmorillonite, the exposure of samples treated with $\mathrm{Fe}^{3+}$ phen to HTP does not induce significant modification of layer structure as evidenced by XRPD data, but rather remarkable ef- fects on pristine $\mathrm{Fe}^{3+}$ phen, with reduction of $\mathrm{Fe}^{3+}$ to $\mathrm{Fe}^{2+}[22] . \mathrm{Fe}^{3+}$ to $\mathrm{Fe}^{2+}$ reduction is likely associated with the oxidation of thiol to disulfide in a redox pathway. After that, the resulting $\mathrm{Fe}^{2+}$ phen rapidly binds a first thiolate ion and, possibly, a second one, according to the following mechanism in which coordinated $\mathrm{H}_{2} \mathrm{O}$ molecules are omitted for clarity sake [22]:

$\left[\text { phenFe }^{3+}-\mathrm{O}-\mathrm{Fe}^{3+} \text { phen }\right]^{4+}+2 \mathrm{RSH}$

$\rightarrow 2[\text { phenFe }]^{2+}+\mathrm{RS}-\mathrm{SR}+\mathrm{H}_{2} \mathrm{O}$ 

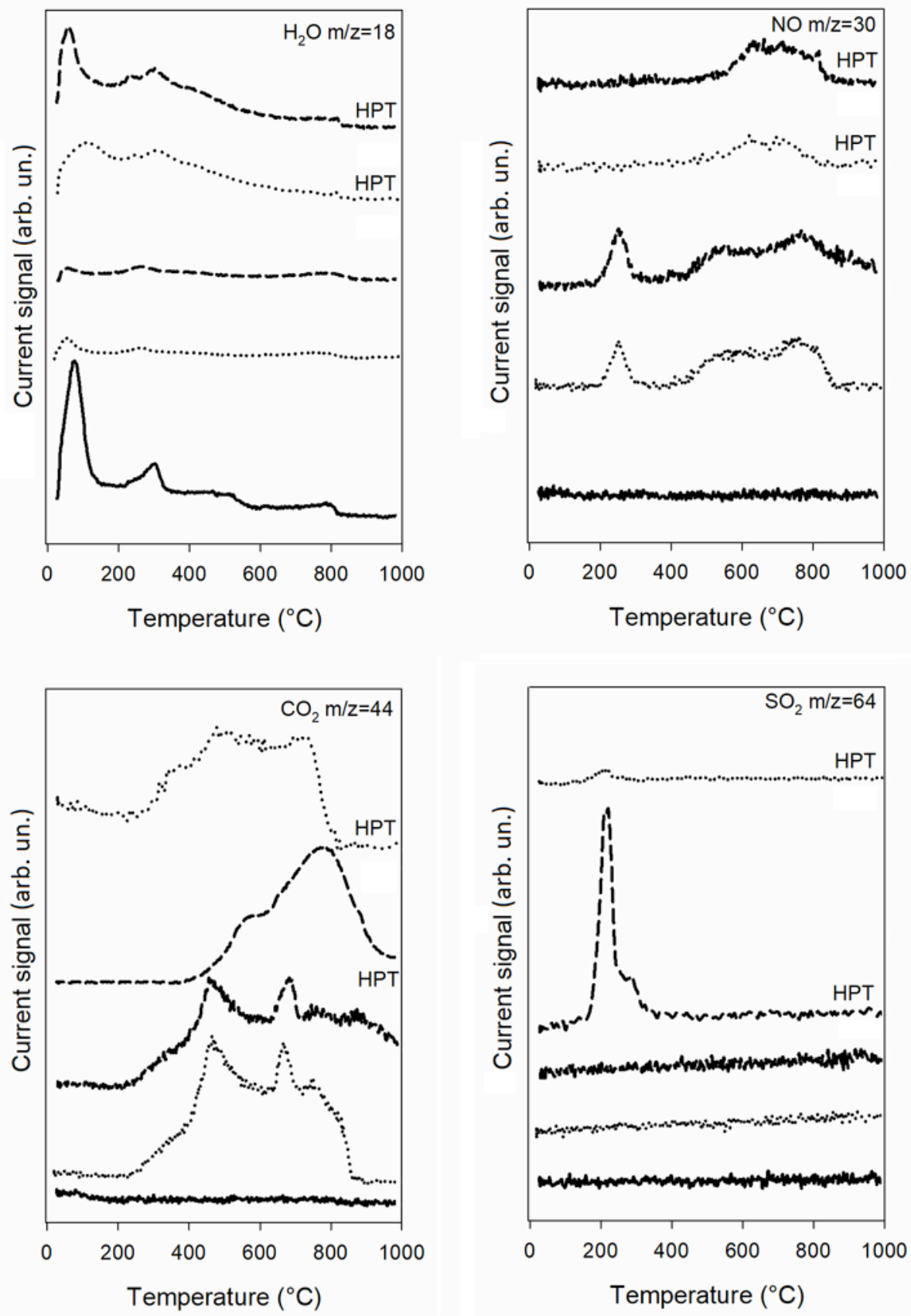

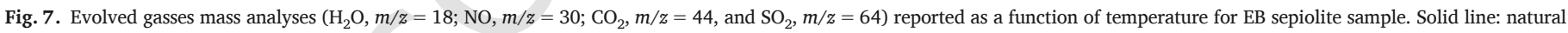

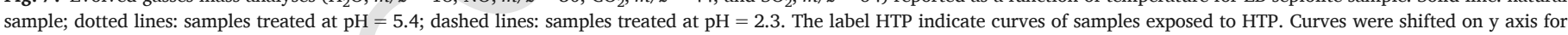
sake of clarity. 


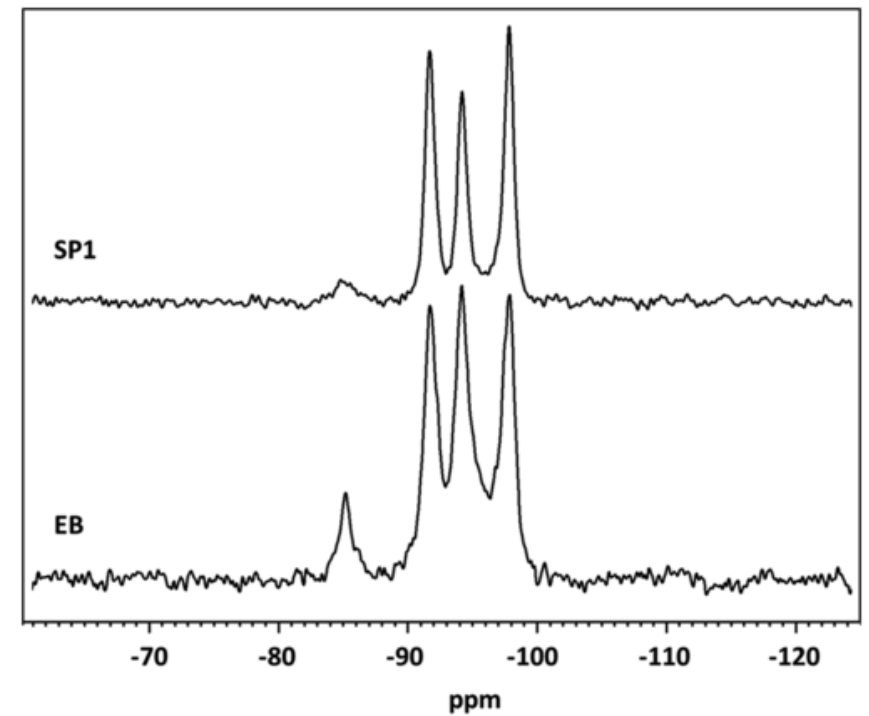

Fig. 8. ${ }^{29} \mathrm{Si}$ CP-MAS NMR spectra of SP1 and EB.

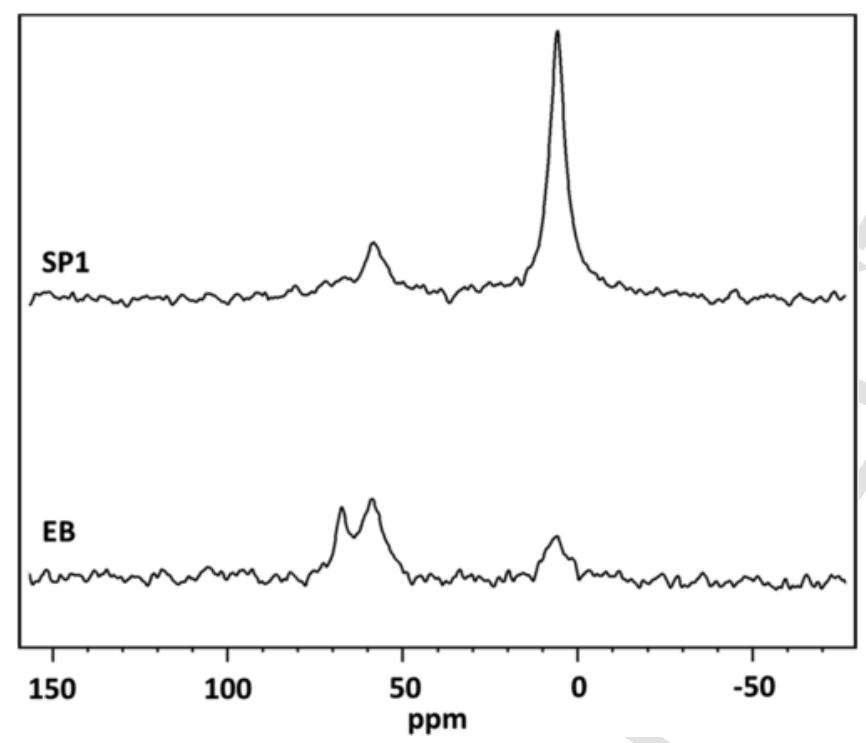

Fig. 9. ${ }^{27} \mathrm{Al} \mathrm{NMR}$ spectra of SP1 and EB.
$2[\mathrm{phenFe}]^{2+}+2 \mathrm{RSH} \rightarrow 2\left[\mathrm{phenFe}^{2+} \mathrm{SR}\right]^{+}+2 \mathrm{H}^{+}$

$2\left[\mathrm{phenFe}^{2+} \mathrm{SR}\right]^{+}+2 \mathrm{RSH}$

$\rightarrow 2\left[\operatorname{phenFe}^{2+}(\mathrm{SR})_{2}\right]+2 \mathrm{H}^{+}(3)$

corresponding to the overall reaction:

$\left[\text { phen }-\mathrm{Fe}^{3+}-\mathrm{O}-\mathrm{Fe}^{3+} \text { phen }\right]^{4+}+6 \mathrm{RSH}$

$\rightarrow \mathrm{RS}-\mathrm{SR}+2\left[\mathrm{phenFe}^{2+}(\mathrm{SR})_{2}\right]+\mathrm{H}_{2} \mathrm{O}+4 \mathrm{H}^{+}$

Thiol is not physi-adsorbed into sepiolite structure, as evidenced by the absence in IR spectra (Fig. 4) of the typical signal related to $\mathrm{S}-\mathrm{H}$ stretching (2550-2600 $\mathrm{cm}^{-1}$ ) that should otherwise be present.

Both $\mathrm{Fe}^{3+}$ phen-treated montmorillonite and sepiolite can thus be used, at room temperature, for removal of thiols present in gas phases. Sepiolite is, however, definitely more effective, as demonstrated by a sulfur content in the reaction products significantly greater than in montmorillonite, although the amount of iron complex adsorbed per unit of mass of sepiolite is extremely less than that immobilized by montmorillonite. In fact, sulfur content in sepiolite SP1 is $8.36 \%$ $(\mathrm{pH}=2.3)$ and $14.88 \%(\mathrm{pH}=5.4)$, while in sepiolite $\mathrm{EB}$ is $12.99 \%$ $(\mathrm{pH}=2.3)$ and $19.42 \%(\mathrm{pH}=5.4)$. In montmorillonite sulfur content is $5.2 \%$ and is independent on $\mathrm{pH}$ value. The total thiol immobilized by montmorillonite treated with $\mathrm{Fe}^{3+}$ phen is the stoichiometric one, corresponding to 3 thiol molecules per iron. The fact that the $\mathrm{Fe}^{3+}$ phen complex immobilized on sepiolite leads to thiol immobilization in much higher quantities than obtained on montmorillonite suggests the presence of a catalytic oxidation mechanism of thiol superimposed on the above mechanism ((1)-(3)). In fact in montmorillonite treated with $\mathrm{Fe}^{3+}$ phen the limit value of the molar ratio S/Fe is 3 [22], while for SP1 at $\mathrm{pH} 2.3$ and 5.4 it is 40 and 81, respectively, and for $\mathrm{EB}$ at $\mathrm{pH} 2.3$ and 5.4 it is 49 and 99, respectively. Nevertheless, we can not exclude that the larger space availability for thiol inside sepiolite channels with respect to montmorillonite interlayer which is filled by strongly intercalated complex molecules could be a further reason for the higher sulfur storage in sepiolite with respect to montmorillonite.

\section{CONCLUSIONS}

$\mathrm{Fe}^{3+}$ phen complex, immobilized on mineral surfaces, is extremely effective as a gas trap for thiols; its efficiency, however, is strongly conditioned by the nature of the interacting surface (or interlayer). This complex adsorbed on sepiolite is able to catch much higher amounts of thiol than the stoichiometric one, probably through a catalytic oxidation mechanism that, conversely, does not occur when $\mathrm{Fe}^{3+}$ phen is intercalated in montmorillonite. The efficiency of this catalytic process, in turn, is significantly affected by the structural features of sepiolite and by $\mathrm{pH}$, as evidenced by the fact that sepiolite EB works better than sepiolite SP1 and thiol removal is larger at $\mathrm{pH} 5.4$ with respect to $\mathrm{pH}$ 2.3. The optimization of an immobilization process of an active chemical species on a mineral surface, therefore, should involve also the tun-

Table 2

${ }^{29} \mathrm{Si}^{\mathrm{a}}$ and ${ }^{27} \mathrm{Al}$ chemical shifts (ppm) of SP1 and EB sepiolite samples. See Figs SM5-SM6 for further details.

\begin{tabular}{|c|c|c|c|c|c|c|c|}
\hline Sample & $\mathrm{Q}^{229} \mathrm{Si}-\mathrm{OH}$ & $\mathrm{Q}^{329} \mathrm{Si}(1)$ & $\mathrm{Q}^{329} \mathrm{Si}(2)$ & $\mathrm{Q}^{329} \mathrm{Si}(3)$ & $\mathrm{M}^{\mathrm{b} 27} \mathrm{Al}$ & $\mathrm{T}(1)^{\mathrm{b} 27} \mathrm{Al}$ & $\mathrm{T}(2)^{\mathrm{b} 27} \mathrm{Al}$ \\
\hline SP1 & -85.1 & -97.8 & -91.7 & -94.2 & 5.7 & 58.4 & nd \\
\hline $\mathrm{EB}$ & -85.2 & -97.8 & -91.8 & -94.2 & 6.1 & 58.9 & 67.7 \\
\hline
\end{tabular}

a Labeled as in Raya et al. (2010) [25].

b $\mathrm{M}=$ octahedral sites, $\mathrm{T}=$ tetrahedral sites (Smith, 1993) [44]. 
ing of the physico-chemical and structural properties of the surface itself.

\section{ACKNOWLEDGMENTS}

Financial support was provided under grants "FFABR (Fondo Finanziamento Attività Base di Ricerca, legge 232/2016)" and "FAR-UNIMORE 2016 PAsTIME". An appreciated support was also provided by Centro Interdipartimentale Grandi Strumenti (CIGS) of Università di Modena e Reggio Emilia and by its staff. Thanks are also due to Fondazione Cassa di Risparmio di Modena for supporting the acquisition of the Bruker $600 \mathrm{MHz}$ NMR spectrometer.

\section{Appendix A. Supplementary data}

Supplementary data to this article can be found online at https:// doi.org/10.1016/j.micromeso.2019.04.054.

\section{Appendix}

Additional information on materials characterization are reported in the Supplementary Materials. Figs. SM1-SM6 report additional data related to NMR spectroscopy (i.e., the deconvolution of CPMAS ${ }^{29} \mathrm{Si}$ (Fig. SM1) and ${ }^{27} \mathrm{Al}$ (Fig. SM2) NMR spectra of natural sepiolites, the ${ }^{1} \mathrm{H}$ NMR spectra of $\mathrm{EB}^{-\mathrm{Fe}^{3+}}{ }^{3}$ phen and EB (Fig. SM3), the deconvolution of ${ }^{1} \mathrm{H}$ NMR spectra of $\mathrm{EB}-\mathrm{Fe}^{3+}$ phen and EB (Fig. SM4), the CP-MAS ${ }^{29} \mathrm{Si}$ NMR spectrum of EB-Fe ${ }^{3+}$ phen (Fig. SM5), and the ${ }^{27} \mathrm{Al}$ NMR spectra of $\mathrm{EB}^{-F^{3+}}{ }^{+}$phen and EB (Fig. SM6). Fig. SM7 reports an expansion of the IR spectra in the wave number range 3800-3500.

\section{References}

[1] E. Galan, Clay Miner. 31 (1996) 443-453, https://doi.org/10.1180/claymin.1996. 031.4.01.

[2] M.F. Brigatti, D. Malferrari, A. Laurora, C. Elmi, in: M.F. Brigatti, A. Mottana (Eds.), Layered Mineral Structures and Their Application in Advanced Technologies, EMU Notes in Mineralogy, 2011, pp. 1-71.

[3] K. Brauner, A. Preisinger, Tschermaks Mineral. Petrogr. Mittl. 6 (1956) 120-140.

[4] J.E. Post, D.L. Bish, P.J. Heaney, Am. Mineral. 92 (2007) 91-97, https://doi.org/ 10.2138/am.2007.2134.

[5] F. Zhou, C.J. Yan, Y. Zhang, J.J. Tan, Appl. Clay Sci. 125 (2016) 119-126 https:// doi.org/10.1016/j.clay.2016.02.013.

[6] E. Ruiz-Hitzky, J. Mater. Chem. 11 (2001) 86-91, https://doi.org/10.1039/ B003197F.

[7] F. Muniz-Miranda, F. Lodesani, F. Tavanti, D. Presti, D. Malferrari, A. Pedone J, Phys. Chem. C 120 (2016) 26945-26954, https://doi.org/10.1021/acs.jpcc. 6b09983.

[8] Q.K. Wang, T. Matsuura, C.Y. Feng, M.R. Weir, C. Detellier, R.L. Rutadinka, R.L. Van Mao, J. Membrane Sci 184 (2001) 153163 https://www.cheric.org/research/ tech/periodicals/doi.php?art_seq $=309285$.

[9] R. Giustetto, K. Seenivasan, S. Bordiga, Period. Mineral. (2010) 21-37, https://doi. org/10.2451/2010PM0019.

[10] R. Giustetto, D. Levy, O. Wahyudi, G. Ricchiardi, J.G. Vitillo, Eur. J. Mineral. 23 (2011) 449-466 https://doi.org/10.1127/0935-1221/2011/0023-2105.

[11] R. Giustetto, K. Seenivasan, F. Bonino, G. Ricchiardi, S. Bordiga, M.R. Chierotti, R. Gobetto, J. Phys. Chem. C 115 (2011) 16764-16776, https://doi.org/10.1021/ jp203270c.

[12] W. Kuang, G.A. Facey, C. Detellier, J. Mater. Chem. 16 (2006) 179-185, https:// doi.org/10.1039/B512575H.
[13] R. M Mamdoh, M.R. Ghada, M. Essam, A.S. Ebtissam, M.E. Ahmed, Appl. Clay Sci. 141 (2017) 72-80 https://doi.org/10.1016/j.clay.2016.12.021.

[14] S. Ovarlez, F. Giulieri, A.M. Chaze, F. Delamare, J. Raya, J. Hirschinger, Chem. Eur J. 15 (2009) 11326-11332 https://doi.org/10.1002/chem.200901482.

[15] E. Sabah, M.S. Çelik, J. Colloid Interface Sci. 251 (2002) 33-38 https://doi.org/10. 1006/jcis.2002.8394.

[16] J. Weng, Z. Gong, L. Liao, G. Lv, J. Tan, Appl. Clay Sci. 161 (2018) 505-512, https: //doi.org/10.1016/j.clay.2018.05.018.

[17] M. Sánchez del Río, E. García-Romero, I. Suárez, M. da Silva, L. Fuentes-Montero, G. Martínez-Criado, Am. Mineral. 96 (2011) 1443-1454, https://doi.org/10.2138/ am.2014.4751.

[18] M. Alvarado Jr., R.C. Chianelli, R.M. Arrowood, Bioinorgan. Chem. Appl. (2012) 672562 https://doi.org/10.1155/2012/672562.

[19] D. Karataş, A. Tekin, M.S. Çelik, Clay Clay Miner. 65 (2017) 1-13, https://doi.org/ 10.1346/CCMN.2016.064043.

[20] F. Bernini, E. Castellini, D. Malferrari, M. Borsari, M.F. Brigatti, Microporous Mesoporous Mater. 211 (2015) 19-29, https://doi.org/10.1016/j.micromeso.2015.02. 039 .

[21] E. Castellini, F. Bernini, M. Borsari, M.F. Brigatti, G.R. Castro, D. Malferrari, L. Medici, A. Mucci, Clay Clay Miner. 65 (2017) 220-233, https://doi.org/10.1346/ CCMN.2017.064065.

[22] F. Bernini, E. Castellini, D. Malferrari, G.R. Castro, C.I. Sainz-Díaz, M.F. Brigatti, M. Borsari, Applied Materials Interfaces 9 (2017) 1045-1056, https://doi.org/10. 1021/acsami.6b11906.

[23] D. Malferrari, E. Castellini, F. Bernini, A. Serrano Rubio, G.R. Castro, C.I. Sainz-Díaz, M. Caleffi, M.F. Brigatti, M. Borsari, Microporous Mesoporous Mater. 265 (2018) 8-17 https://doi.org/10.1016/j.micromeso.2018.01.017.

[24] R. Sui, S.K. Carefoot, C.B. Lavery, C.E. Deering, K.L. Lesage, N. Chou, C.J. Rose, R.A. Marriott, J. Mat.s Chem. A 5 (2017) 9561-9571, https://doi.org/10.1039/ C7TA01856H.

[25] J. Raya, J. Hirschinger, S. Ovarlez, F. Giulieri, A.M. Chaze, F. Delamare, Phys. Chem. Chem. Phys. 43 (2010) 14508-14514, https://doi.org/10.1039/ c0cp00834f.

[26] M.F. Brigatti, C.I. Sainz Dìaz, M. Borsari, F. Bernini, E. Castellini, D. Malferrari, Rend. Fis. Acc. Lincei (2017) https://doi.org/10.1007/s12210-017-0615-1.

[27] A. Alietti, M.F. Brigatti, L. Poppi, Rend. Soc. It. Miner. Petrol. 39 (1984) 163-172.

[28] K. Stahr, M. Zarei, R. Jahn, Mittl. Dtsch. Bodenkd. Ges. 62 (1990) 147-150.

[29] A. Singer, K. Stahr, M. Zarei, Clay Miner. 33 (1998) 349-362.

[30] A.M.A. Gure, Bristol, UK: Sunlight Water and Environmental Consultancy Services, 2015.

[31] C. He, E. Makovicky, B. Osbaeck, Appl. Clay Sci. 10 (1996) 337-349 https://doi. org/10.1016/0169-1317(95)00035-6.

[32] E. Galán, M. Pozo (Eds.), Palygorskite and sepiolite deposits in continental environments. Description, genetic patterns and sedimentary settings. Development of Clay Science, 3, Elsevier, 2011, pp. 125-173, 978-0-444-53607-5.

[33] F. Franco, M. Pozo, J.A. Cecilia, M. Benítez-Guerrero, E. Pozo, J.A. Martín Rubí, Appl. Clay Sci. 102 (2014) 15-27 https://doi.org/10.1016/j.clay.2014.10.013.

[34] W.R. McWhinnie, J.D. Miller, The Chemistry of Complexes Containing 2,2'-Bipyridyl, 1,10-phenanthroline or 2,2',6',2' '-Terbipyridyl as ligands, In: H.J. Hemeléus, A.G. Sharpe (Eds.), Advances in Inorganic Chemistry and Radiochemistry, vol. 12, Academic Press, New York, 1961, p. 163.

[35] R.L. Frost, O.B. Locos, H. Ruan, J.T. Kloprogge, Vib. Spectrosc. 27 (2001) 1-13.

[36] R.L. Frost, G.A. Cash, J.T. Kloprogge, Vib. Spectrosc. 16 (1998) 173-184.

[37] V.C. Farmer, The layer silicates, in: V.C. Farmer (Ed.), The Infrared Spectra of Minerals, Mineralogical Society, London, 1974, pp. 331-363, Monogra ph 4.

[38] A.M. Sevim, R. Hojiyev, A. Gül, M.S. Celik, Dyes Pigments 88 (2011) 25-38, https: //doi.org/10.1016/j.dyepig.2010.04.011.

[39] M. Pozo, J.P. Calvo, E. Pozo, A. Moreno, Appl. Clay Sci. 91-92 (2014) 30-45 https: //doi.org/10.1016/j.clay.2014.02.005

[40] L. Bertilsson, R. Liedberg, B., Langmuir 9 (1993) 141-149.

[41] T. M Uehara, H.B. de Aguiar, K. Bergamaski, P.B. Miranda, J. Phys. Chem. C 118 (2014) 20374-20382, https://doi.org/10.1021/jp5054919.

[42] N. Yener, M. Önal, G. Üstünışık, Y. Sarıkaya, J. Therm. Anal. Calorim. 88 (2007) 813-817 https://doi.org/10.1007/s10973-005-7459-0.

[43] M.R. Weir, W. Kuang, G.A. Facey, C. Detellier, Clay Clay Miner. 51 (2003) 318-326, https://doi.org/10.1346/CCMN.2003.0510308.

[44] M.E. Smith, Appl. Magn. Reson. 4 (1993) 1-64.

[45] G. Rytwo, S. Nir, L. Margulies, B. Casal, J. Merino, E. Ruiz-Hitzky, J.M. Serratosa, Clay Clay Miner. 46 (1998) 340-348. 